\title{
Simultaneous Removal of SO2 and NOx From Flue Gas by Low-temperature Adsorption Over Activated Carbon
}

Shiqing Wang ( $\sim$ sq_wang@qny.chng.com.cn )

Huaneng Clean Energy Research Institute

Qixiang Fan

China Huaneng Group Co., Ltd.

Shisen Xu

China Huaneng Group Co., Ltd.

Shiwang Gao

Beijing Key Laboratory of CO2 Capture and Process

\section{Ping Xiao}

State Key Laboratory of coal based Clean Energy

\section{Minhua Jiang}

China Huaneng Group Co., Ltd.

He Zhao

China Huaneng Group Co., Ltd.

\section{Bin Huang}

China Huaneng Group Co., Ltd.

Lianbo Liu

Huaneng Clean Energy Research Institute

Hongwei Niu

Huaneng Clean Energy Research Institute

Jinyi Wang

Beijing Key Laboratory of CO2 Capture and Process

Dongfang Guo

Beijing Key Laboratory of CO2 Capture and Process

\section{Research Article}

Keywords: Low-temperature adsorption, Activated carbon, Desulfurization, Denitrification

Posted Date: November 25th, 2020

DOl: https://doi.org/10.21203/rs.3.rs-109487/v1 
License: (c) (i) This work is licensed under a Creative Commons Attribution 4.0 International License. Read Full License 


\title{
Simultaneous Removal of $\mathrm{SO}_{2}$ and NOx from
}

\section{Flue Gas by Low-temperature Adsorption over Activated Carbon}

\author{
Shiqing Wang ${ }^{2}$, Qixiang Fan ${ }^{2}$, Shisen Xu², Shiwang Gao ${ }^{3}$, Ping Xiao ${ }^{4}$, Minhua Jiang ${ }^{2}$, He Zhao , \\ Bin Huang ${ }^{2}$, Lianbo Liu ${ }^{1}$, Hongwei Niu ${ }^{1}$, Jinyi Wang ${ }^{3}$, Dongfang Guo ${ }^{3}$ \\ 1. Huaneng Clean Energy Research Institute, Beijing, 102209, China \\ 2. China Huaneng Group Co., Ltd., Beijing, 100031, China \\ 3. Beijing Key Laboratory of $\mathrm{CO}_{2}$ Capture and Process, Beijing, 102209, China \\ 4. State Key Laboratory of coal based Clean Energy, Beijing, 102209, China
}

*Correspondence to: $\underline{\text { sq_wang@gny.chng.com.cn }}$

\begin{abstract}
An exceptional phenomenon has been observed that nitrogen monoxide can be effectively adsorbed over activated carbon at cold temperatures with the presence of oxygen. Based on this finding, a novel lowtemperature adsorption process is developed to simultaneously remove $\mathrm{SO}_{2}$ and $\mathrm{NOx}$ from flue gas with a target of near-zero emission. In this study, the adsorption characteristics of $\mathrm{NO}$ and $\mathrm{SO}_{2}$ over activated carbon at various temperatures $\left(-20,0,20\right.$ and $\left.80^{\circ} \mathrm{C}\right)$ are experimentally investigated. For $\mathrm{NO}-\mathrm{O}_{2}$ co-adsorption, $\mathrm{NO}-\mathrm{NO}_{2}$ equilibriums with increasing $\mathrm{NO}_{2}$ concentration along the the adsorption bed are established due to the catalytic oxidation of $\mathrm{NO}$ over activated carbon. Co-adsorption of $\mathrm{NO}-\mathrm{NO}_{2}$ occurs at each cross section of the adsorption bed and the adsorption capability increases along the adsorption bed with increasing $\mathrm{NO}_{2}$ concentrations. The oxidation rate of $\mathrm{NO}$ can be significantly enhanced at cold temperatures, which leads to an extraordinary improvement of NO adsorption. At a space velocity of $5000 \mathrm{~h}^{-1}$ and an initial $\mathrm{NO}$ concentration of $200 \mathrm{ppmv}$, the breakthrough time increases from 3.49 to 1591.75 minutes when the temperature decreases from 80 to $-20^{\circ} \mathrm{C}$. In addition, the adsorption capacity of $\mathrm{SO}_{2}$ is also dramatically increased at cold temperatures. At a space velocity of $5000 \mathrm{~h}^{-1}$ and an initial $\mathrm{SO}_{2}$ concentration of $1000 \mathrm{ppmv}$, the breakthrough time increase from 20 to 265 minutes when the temperature decreases from 80 to $-20^{\circ} \mathrm{C}$. A pilot-scale testing platform with a flue gas flowrate of 3600 $\mathrm{Nm}^{3} / \mathrm{h}$ is developed to validate this novel adsorption process for simultaneous desulfurization and denitrification. Emission of both $\mathrm{SO}_{2}$ and $\mathrm{NOx}$ is less than $1 \mathrm{mg} / \mathrm{Nm}^{3}$, and the predicted energy penalty is about $3 \%$ of the net generation.
\end{abstract}

Key Words: Low-temperature adsorption, Activated carbon, Desulfurization, Denitrification 


\section{Introduction}

$\mathrm{SO}_{2}$ and $\mathrm{NOx}$ in flue gas are major air pollutants responsible for acid rain and photochemical smog. $\mathrm{SO}_{2}$ is an acidic gas and can be scrubbed by alkalic solutions such as lime, sodium carbonate, ammonia, seawater, etc[1, 2]. $\mathrm{NOx}$ in flue gas is mainly composed of $\mathrm{NO}$ which can be either reduced to $\mathrm{N}_{2}$ by selective catalytic reduction (SCR technology) technology or oxidized to $\mathrm{NO}_{2}$ (SCO technology) which can be scrubbed by alkalic solutions[3]. Wet flue gas desulfurization (WFGD) and SCR dinitrification are the dominant technologies in power plants nowadays.

In addition, adsorption technology has also been widely used for gas cleanup. Simultaneous removal of $\mathrm{SO}_{2}$ and NOx by activated carbon or coke has been successfully demonstrated in flue gas treatment[4, 5]. An schematic drawing of the process is shown in Fig.1[6]. The removal of $\mathrm{SO}_{2}$ over activated carbon in the presence of oxygen and moisture involves a series of reactions that leads to the formation of sulfuric acid. The used carbon is regenerated through heating to recover their adsorbing activity. The desorbed $\mathrm{SO}_{2}$ is recycled as elemental sulfur, sulfuric acid or liquid $\mathrm{SO}_{2}$. The typical operating temperature is $80-150^{\circ} \mathrm{C}$ in the adsorber and $350-450{ }^{\circ} \mathrm{C}$ in the regenerator. The overall adsorption and desorption reactions are as follows[7]:

$$
\begin{aligned}
& 2 \mathrm{SO}_{2}+\mathrm{O}_{2}+2 \mathrm{H}_{2} \mathrm{O}+2 \mathrm{C} * 2 \mathrm{C}^{*} \mathrm{H}_{2} \mathrm{SO}_{4} \\
& 2 \mathrm{H}_{2} \mathrm{SO}_{4}+\mathrm{C} \rightarrow 2 \mathrm{SO}_{2}+\mathrm{CO}_{2}+2 \mathrm{H}_{2} \mathrm{O}
\end{aligned}
$$

NOx is removed through selective catalytic reduction over activated carbon by reacting with injecting $\mathrm{NH}_{3}$. The overall reactions are as follows[8]:

$$
\begin{aligned}
& 4 \mathrm{NO}+4 \mathrm{NH}_{3}+\mathrm{O}_{2} \rightarrow 4 \mathrm{~N}_{2}+6 \mathrm{H}_{2} \mathrm{O} \\
& 6 \mathrm{NO}_{2}+8 \mathrm{NH}_{3} \rightarrow 7 \mathrm{~N}_{2}+12 \mathrm{H}_{2} \mathrm{O}
\end{aligned}
$$

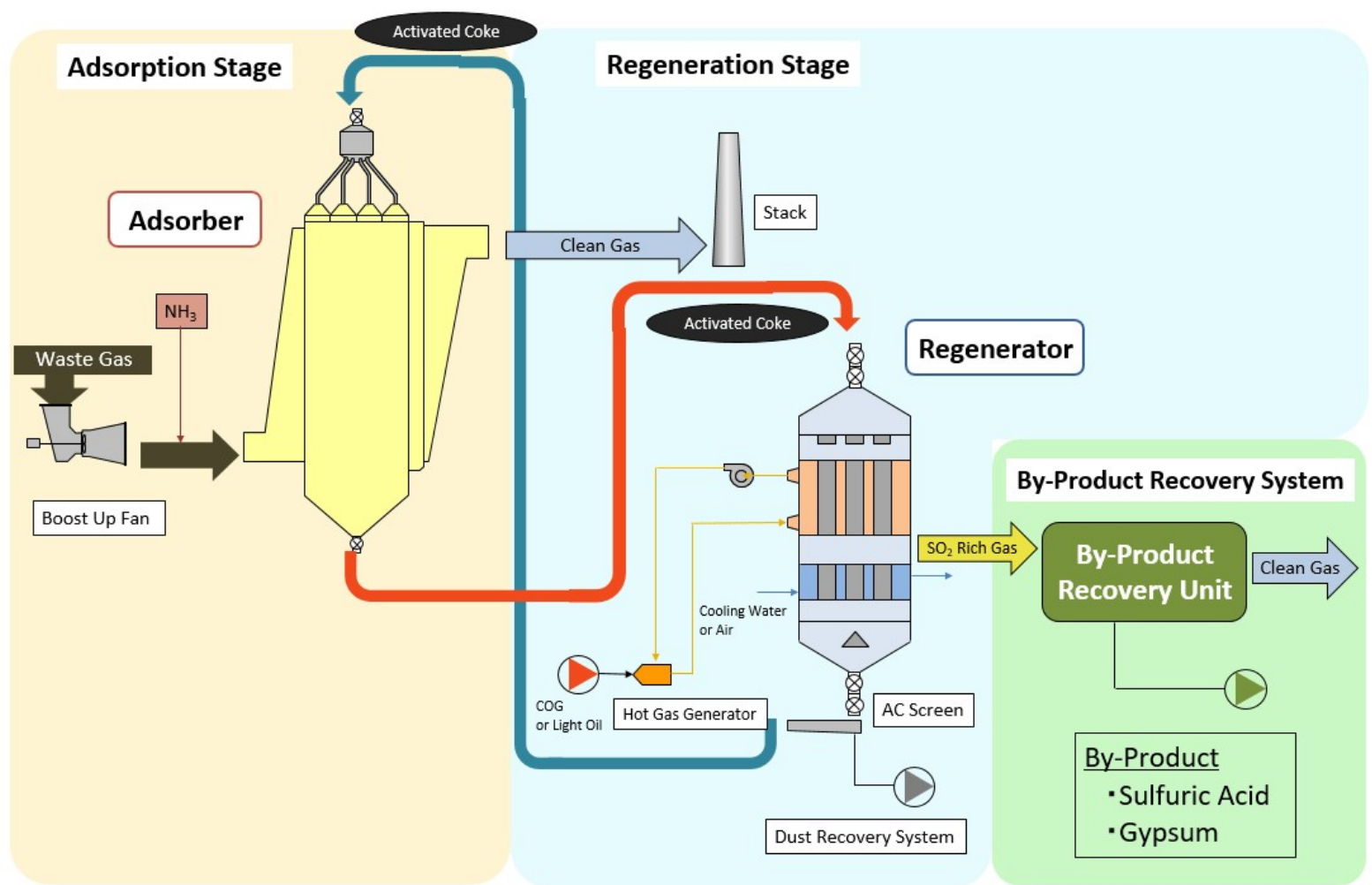


Figure 1 Schematic drawing of the activated coke desulfurization and denitrification process[6]

This technology has several advantages compared to traditional WFGD and SCR technologies. It can remove $\mathrm{SO}_{2}$, NOx, particulate, $\mathrm{Hg}$ and other adsorbable pollutants simultaneously. It has no alkalic chemicals consumption and no waste water generation. This technology has been widely used for sintering flue gas treatment in iron and steel industry[9]. However, it has several defects which weaken its competiveness. First of all, the $\mathrm{SO}_{2}$ adsorption capacity is small which makes it not suitable for power plant flue gas with high $\mathrm{SO}_{2}$ concentration and large flue gas flowrate. Only a few applications of this technology in power plants have been reported[10]. Secondly, NO shows poor adsorbability over activated carbon, and can not be removed simultaneously with $\mathrm{SO}_{2}$ through adsorption. By introducing $\mathrm{NH}_{3}$ to the flue gas, $\mathrm{NOx}$ can be reduced to $\mathrm{N}_{2}$ through catalytic reduction over activated carbon and a deNOx rate of about $70 \%$ can be achieved[11], which is not sufficient enough to meet the emission control requirement in power plant. Abundant of effort has been made to enhance the adsorbablility of $\mathrm{SO}_{2}$ and $\mathrm{NOx}$ by either using modified activated carbon[12,13] or other solid adsorbent such as activated carbon fibers[14], molecular sieve[15, 16], alumina substrate impregnated with sodium carbonate (NOXSO process)[17], copper oxide[18], etc. But none of these technologies has been successfully commercialized.

This study is inspired by an exceptional phenomenon observed accidentally that NO can be adsorbed by activated carbon with an astonishing efficiency and capacity when flue gas is cooled to cold temperatures. In addition, the adsorption efficiency and capacity of $\mathrm{SO}_{2}$ is also dramatically increased at cold temperatures. Based on this finding, a novel low-temperature adsorption process is developed to simultaneously remove $\mathrm{SO}_{2}$ and $\mathrm{NOx}$ from flue gas with a target of near-zero emission. This study has a focus on the fundamental behaviors of $\mathrm{NO}$ and $\mathrm{SO}_{2}$ adsorption at cold temperatures. An attempt to investigate the oxidation and adsorption mechanism of NO over activated carbon at cold temperatures is also included. Furthermore, a pilot-scale testing platform with a flue gas treatment capacity of $3600 \mathrm{Nm}^{3} / \mathrm{h}$ is designed and built to validate this new desulfurization and denitrification technology. A brief introduction and first-hand data from the pilot-scale testing facility is also shared in this study.

\section{Method}

\subsection{Material}

Commercial coconut activated carbon (CAC) with granular size between 26-30 mesh is used in this study. The surface physical properties of CAC is characterized by BET method (Quantachrome QUDRASORB SI). The specific surface area of CAC is $1314.5 \mathrm{~m}^{2} / \mathrm{g}$, the pore width is mainly smaller than $2 \mathrm{~nm}$, as shown in Fig.2. CAC is pretreated by heating to $300^{\circ} \mathrm{C}$ in an vacuum tube for $2 \mathrm{hrs}$ before each test. Mass of CAC is measured after the pretreatment. The loading density of granular CAC is $0.5 \mathrm{~g} / \mathrm{cm}^{3}$.

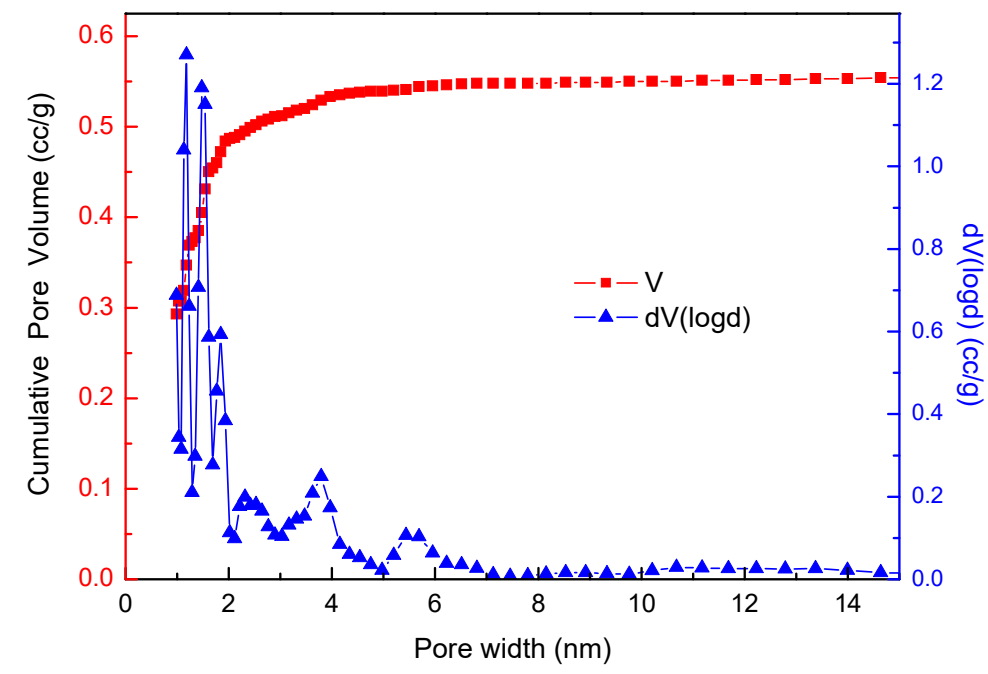


Figure 2 Pore distribution of coconut activated carbon

\subsection{Experimental Setup}

The experimental setup for investigating the adsorption behaviors of $\mathrm{SO}_{2}$ and $\mathrm{NO}$ at cold temperatures are shown in Fig. 3. Simulated flue gas has a typical composition of $\mathrm{N}_{2}, \mathrm{O}_{2}, \mathrm{CO}_{2}, \mathrm{SO}_{2}, \mathrm{NO}$ and $\mathrm{H}_{2} \mathrm{O}$. The concentration of each species can be adjusted by flow controller. Moisture in flue gas is added by a water injector controlled by a stepper motor. The flue gas in pre-heated or pre-cooled to adsorption temperature by a coiled copper pipe immersing in a thermostatic bath with a temperature range of $-40 \sim 100^{\circ} \mathrm{C}$. The granular activated carbon is loaded in a glass tube with an inner diameter of $5 \mathrm{~mm}$ which is also immersed in the thermostatic both. The gas composition of flue gas before and after adsorption is measured by flue gas analyzer testo 350 which has a resolution of 1 ppmv for measuring $\mathrm{NO}, \mathrm{NO}_{2}$ and $\mathrm{SO}_{2}$. The dry flue gas has a volume flow rate of $\mathrm{Q}=1 \mathrm{~L} / \mathrm{min}$. And the space velocity of adsorption bed is $5000 \mathrm{~h}^{-1}$.

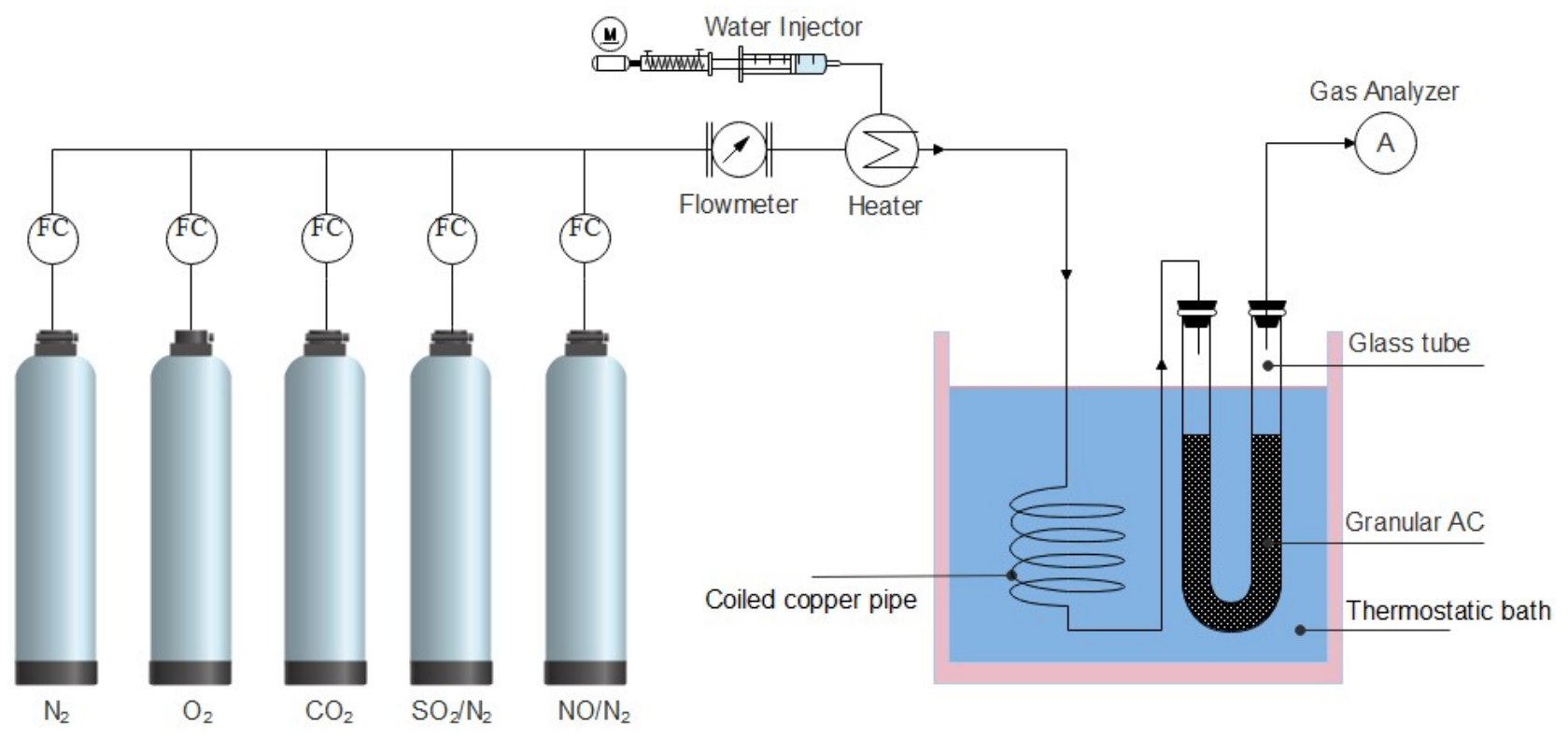

Figure 3 Experimental setup for low-temperature adsorption of $\mathrm{SO}_{2}$ and $\mathrm{NO}$

\subsection{Pilot platform}

A pilot-scale test platform is designed to simultaneously remove $\mathrm{SO}_{2}, \mathrm{NOx}$ and other adsorbable pollutants based on the novel low-temperature adsorption process. The designed flue gas flowrate is $3600 \mathrm{Nm} / \mathrm{h}$. The lowest operating temperature is $-20^{\circ} \mathrm{C}$. The pollutants control target is near-zero emission: $\mathrm{SO}_{2}$ and $\mathrm{NOx} \leqq 1 \mathrm{mg} / \mathrm{Nm}{ }^{3}$.

A schematic flowchart of the pilot-scale test platform is shown in Fig.4. Flue gas is extracted from the inlet duct before SCR deNOx system. Hot flue gas is cooled to around $120^{\circ} \mathrm{C}$ by an air preheater and the dust is then removed by a bag-type dust remover. Flue gas is further cooled to around $70^{\circ} \mathrm{C}$ by a residue heat recovery exchanger (HX1) which can generate usable hot water. Flue gas is cooled to cold temperatures by a direct contact cooling (DCC) tower which has three cooling stages. In the lower stage (stage 1), flue gas is cooled close to room temperature by water scrubbing and the cooling load is provided by cooling water; in the second stage (stage 2), flue gas is cooled to $2 \sim 5^{\circ} \mathrm{C}$ by cold water scrubbing and the cooling load is provided by an industrial chiller; in the upper stage (stage 3), flue gas is cooled to below freezing point by calcium chloride solution scrubbing and the cooling load is provided by an industrial refrigerator. The cold flue gas enters the adsorber in which $\mathrm{SO}_{2}$ and NOx are removed by activated carbon through adsorption. The cold energy of clean flue gas is recovered by cooling the scrubbing water in the DCC cooling tower through HX2. The saturated activated carbon is heated in 
the regenerator to recover its adsorption activity for repeatable utilization. The desorbed $\mathrm{SO}_{2}$ can be recovered as elemental sulfur or sulfuric acid, and the desorbed NOx can be introduced to the boiler to form a stable thermal balance of NOx- $\mathrm{N}_{2}-\mathrm{O}_{2}$, which has been successfully demonstrated in the NOXSO process[17]. In this pilot study however, the post-treatment of desorbed gas is not considered.

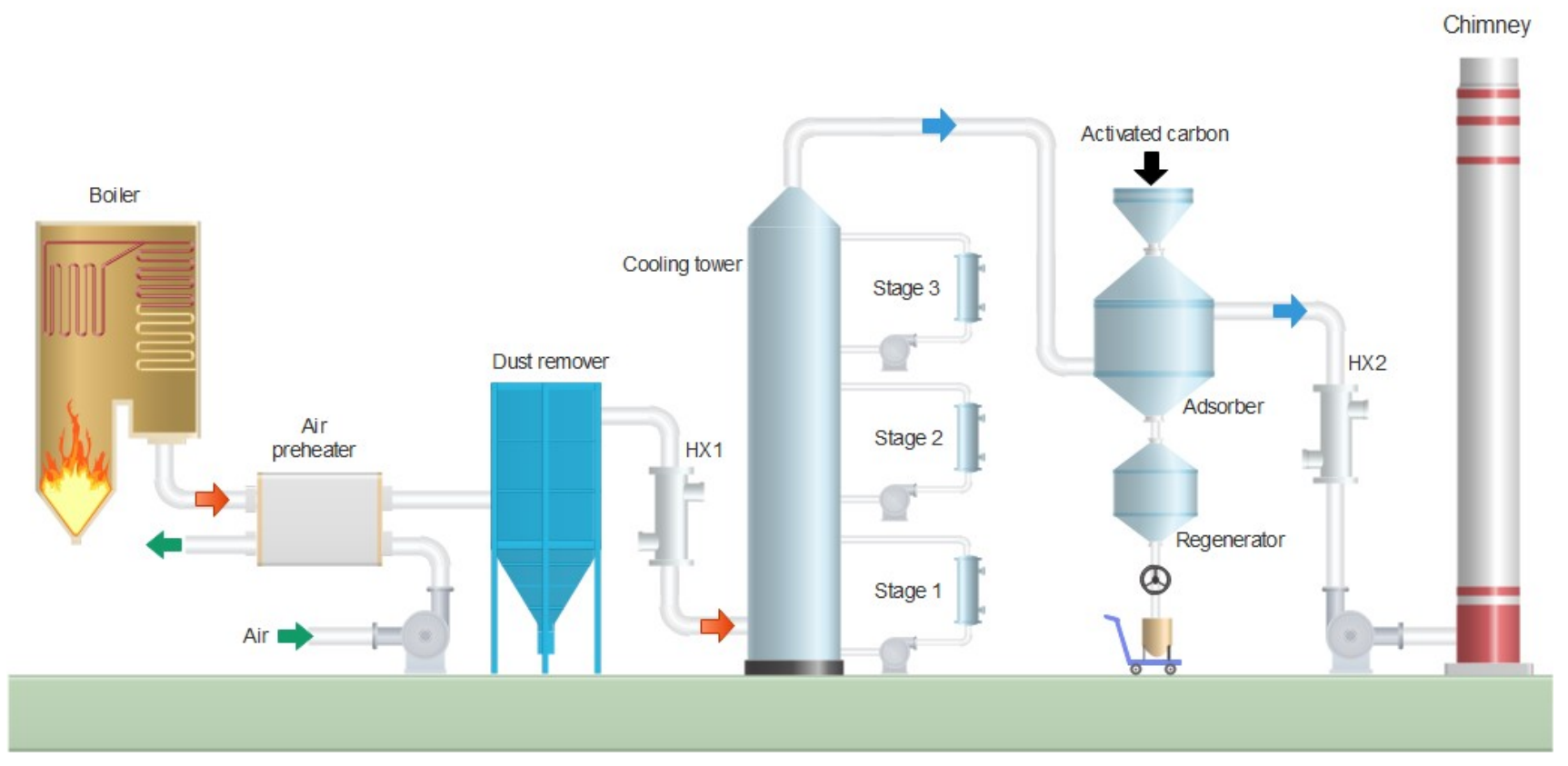

Figure 4 Schematic flowchart of pilot-scale test platform

\section{Results and Discussions}

\subsection{Phenomenon}

This study is enlightened by an unexpected observation on the simultaneous adsorption of $\mathrm{SO}_{2}$ and $\mathrm{NOx}$ in flue gas at low temperatures. The experiment is conducted based on the setup as shown in Fig.3. The simulated flue gas has volume concentration of $\mathrm{SO}_{2}=1000 \mathrm{ppmv}, \mathrm{NO}=200 \mathrm{ppmv}, \mathrm{O}_{2}=6 \mathrm{v} \%$ and $\mathrm{CO}_{2}=12 \mathrm{v} \%$ on a dry flue gas basis. The dry flue gas has a volume flow rate of $1 \mathrm{~L} / \mathrm{min}$. The water content is $10 \mathrm{v} \%$ at $80^{\circ} \mathrm{C}, 2.3 \mathrm{v} \%$ (saturated) at $20^{\circ} \mathrm{C}, 0.1 \mathrm{v} \%$ (saturated) at $-20^{\circ} \mathrm{C}$, respectively. The breakthrough curve of $\mathrm{SO}_{2}$ and $\mathrm{NO}$ is given in Fig.5.

At $80^{\circ} \mathrm{C}$, which is close to the typical operating temperature of traditional activated carbon desulfurization and denitrification technology, NO breaks through the adsorption bed almost instantaneously. At $20^{\circ} \mathrm{C}$, the breakthrough time of $\mathrm{NO}$ is about 5 minutes and at $-20^{\circ} \mathrm{C}$, the breakthrough time increases dramatically to about 225 minutes. This observation indicates that removal of $\mathrm{NO}$ by adsorption is inefficient at above room temperatures, therefore SCR by introducing $\mathrm{NH}_{3}$ to the flue gas has to be applied. However, $\mathrm{NO}$ can be efficiently adsorbed with a large capacity at cold temperatures. In addition, the adsorption of $\mathrm{SO}_{2}$ is also dramatically enhanced at cold temperatures. The breakthrough time increases from 20 minutes at $80^{\circ} \mathrm{C}$ to about 295 minutes at $-20^{\circ} \mathrm{C}$. This phenomenon has inspired the team to develop a novel flue gas treatment process in which $\mathrm{SO}_{2}, \mathrm{NOx}$ and other adsorbable pollutants are removed by adsorption at cold temperatures. To achieve such an ambitious attempt, related scientific details and engineering challenges has be to solved. 

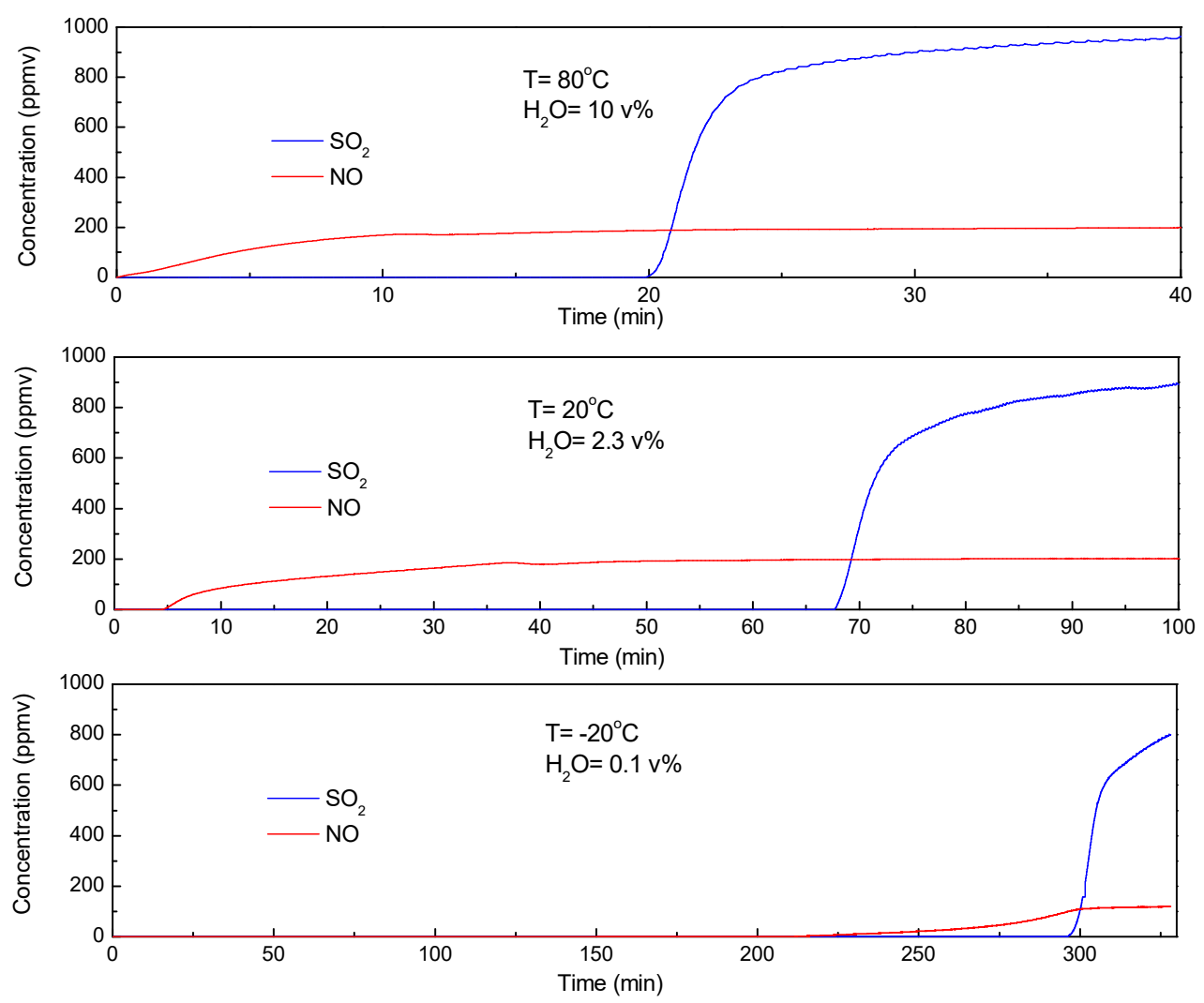

Figure 5 Adsorption breakthrough curves of $\mathrm{SO}_{2}$ and $\mathrm{NO}$ adsorption at various temperatures $\left(\mathrm{SO}_{2}=1000\right.$ ppmv, $\mathrm{NO}=200 \mathrm{ppmv}, \mathrm{O}_{2}=6 \mathrm{v} \%, \mathrm{CO}_{2}=12 \mathrm{v} \%$, space velocity $\left.=5000 \mathrm{~h}^{-1}\right)$

\subsection{Adsorption of NO}

The adsorption characteristics of $\mathrm{NO}$ and $\mathrm{NO}-\mathrm{O}_{2}$ over $\mathrm{CAC}$ at $80,20,0$ and $-20^{\circ} \mathrm{C}$ is studied. The inlet gas has an NO concentration of $C_{i n}=200 \mathrm{ppmv}$, equivalent to $410 \mathrm{mg} / \mathrm{Nm}^{3}$ in terms of NOx which is a typical concentration in coal-fired flue gas. The balance gas is $\mathrm{N}_{2}$. About 6 grams of pretreated CAC is loaded in the adsorption pipe and the space velocity is $5000 \mathrm{~h}^{-1}$.

For $\mathrm{NO}$ adsorption over $\mathrm{CAC}$ without the presence of oxygen, the time-dependent concentration of $\mathrm{NO}$ at the exit of adsorption pipe is given in Fig.6. The breakthrough time and adsorption capacity are given in Tab.1. The adsorption capacity is calculated by the following equations:

$$
\begin{aligned}
& A_{b}=\frac{C_{\text {in }} \times t_{b} \times Q \times M}{22.4 \times m} \times 10^{-3} \\
& A_{s}=\frac{\int\left(C_{\text {in }}-C_{\text {out }}(\mathrm{t})\right) \times Q \times M \times d t}{22.4 \times m} \times 10^{-3}
\end{aligned}
$$

where breakthrough time $\left(t_{b}\right.$, minutes) is defined as the adsorption time when $C_{\text {out }}(\mathrm{t}) \leqq 1$ ppmv (testo 350 has a resolution of $1 \mathrm{ppmv}$ ), and the corresponding adsorption capacity is defined as breakthrough adsorption capacity $\left(A_{b}, \mathrm{mg} / \mathrm{g}\right)$. Saturated adsorption capacity $\left(A_{s}, \mathrm{mg} / \mathrm{g}\right)$ is defined as the maximum adsorption capacity of the loaded 
CAC bed. $C_{\text {in }}$ and $C_{\text {out }}(\mathrm{t})$ are the NO concentration (ppmv) at the inlet and outlet of adsorption bed. Q is the flow rate $(\mathrm{L} / \mathrm{min})$ of simulated flue gas. $\mathrm{M}$ is the molecular weight $(\mathrm{g} / \mathrm{mol})$. $\mathrm{m}$ is the mass (gram) of loaded CAC.

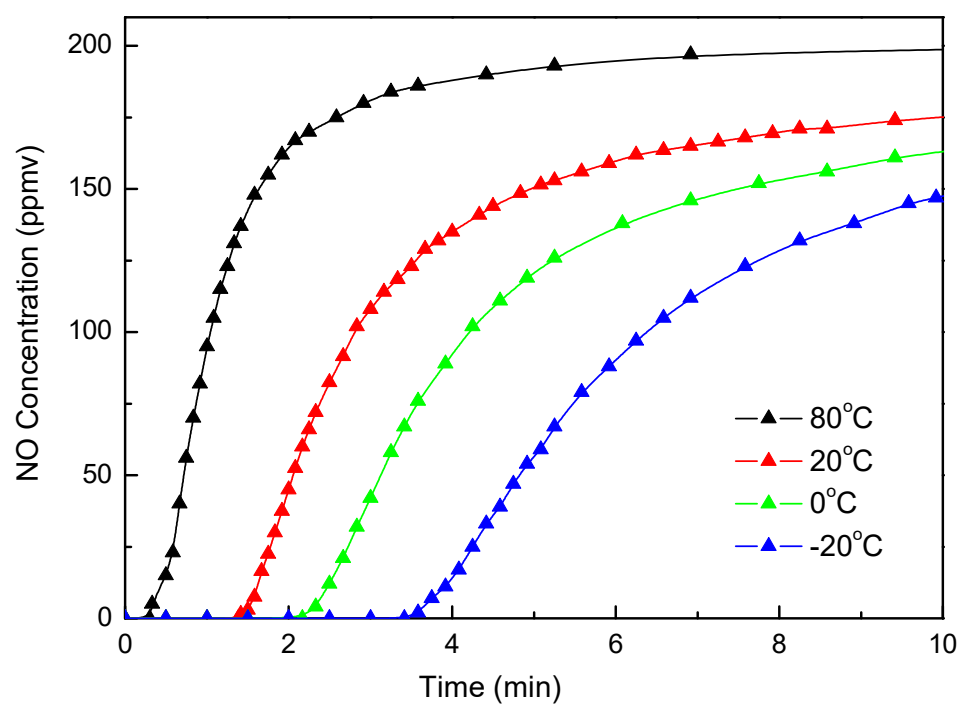

Figure 6 Adsorption breakthrough curve of $\mathrm{NO}$ at various temperatures $\left(\mathrm{NO}=200 \mathrm{ppmv}\right.$, space velocity $\left.=5000 \mathrm{~h}^{-1}\right)$

Without the presence of oxygen, the physisorption (Van der Waals adsorption) of NO over activated carbon is enhanced by decreasing the adsorption temperature since physisorption is an exothermic process[19]. In general, without the presence of oxygen, the adsorption capacity of NO is very small and it is not feasible to remove NO from flue gas through physisorption by activated carbon.

With the presence of oxygen, $\mathrm{NO}$ can be oxidized to $\mathrm{NO}_{2}$ over activated carbon[20, 21], a steady $\mathrm{NO}-\mathrm{NO}_{2}$ equilibrium will be formed at the exit of activated carbon bed[22, 23]. For $\mathrm{NO}_{2} \mathrm{O}_{2}$ co-adsorption over CAC at various temperature, the time-dependent concentration of $\mathrm{NO}$ and $\mathrm{NO}_{2}$ at the exit of adsorption pipe is given in Fig.7. The breakthrough time and adsorption capacity are given in Tab.1. When calculating the saturated adsorption capacity, $C_{\text {out }}(\mathrm{t})=C_{\text {out }}(\mathrm{NO})+C_{\text {out }}\left(\mathrm{NO}_{2}\right)$ in the case of $\mathrm{NO}-\mathrm{O}_{2}$ co-adsorption.

The presence of oxygen can significantly increase the adsorbability of NO because of the catalytic oxidation of $\mathrm{NO}$ to $\mathrm{NO}_{2}$ which is a much more adsorbable species over activated carbon[24, 25]. The oxidation conversion rate $\eta\left(\mathrm{NO}_{2}\right)$ is given in Fig. 8 and Tab.1.

Table 1 Adsorption characteristics of $\mathrm{NO}$ and $\mathrm{NO}-\mathrm{O}_{2}$ over $\mathrm{CAC}$ at various temperatures $\left(\mathrm{NO}=200 \mathrm{ppmv}, \mathrm{O}_{2}=6 \mathrm{v} \%\right.$, space velocity $\left.=5000 \mathrm{~h}^{-1}\right)$

\begin{tabular}{|c|c|c|c|c|c|c|c|}
\hline \multirow{2}{*}{ Temperature, ${ }^{\circ} \mathrm{C}$} & \multicolumn{3}{|c|}{ NO adsorption } & \multicolumn{4}{c|}{${\mathrm{NO}-\mathrm{O}_{2} \text { co-adsorption }}$} \\
\cline { 2 - 8 } & $t_{b}, \mathrm{~min}$ & $A_{b}, \mathrm{mg} / \mathrm{g}$ & $A_{s}, \mathrm{mg} / \mathrm{g}$ & $t_{b}, \mathrm{~min}$ & $A_{b}, \mathrm{mg} / \mathrm{g}$ & $A_{s}, \mathrm{mg} / \mathrm{g}$ & $\eta\left(\mathrm{NO}_{2}\right), \%$ \\
\hline 80 & 0.25 & 0.011 & 0.066 & 3.49 & 0.156 & 3.765 & 2.0 \\
\hline 20 & 1.38 & 0.062 & 0.213 & 55.82 & 2.492 & 45.333 & 45.0 \\
\hline 0 & 2.17 & 0.097 & 0.332 & 392.40 & 17.518 & 116.349 & 69.0 \\
\hline-20 & 3.42 & 0.153 & 0.434 & 1591.75 & 71.061 & 169.142 & 91.5 \\
\hline
\end{tabular}



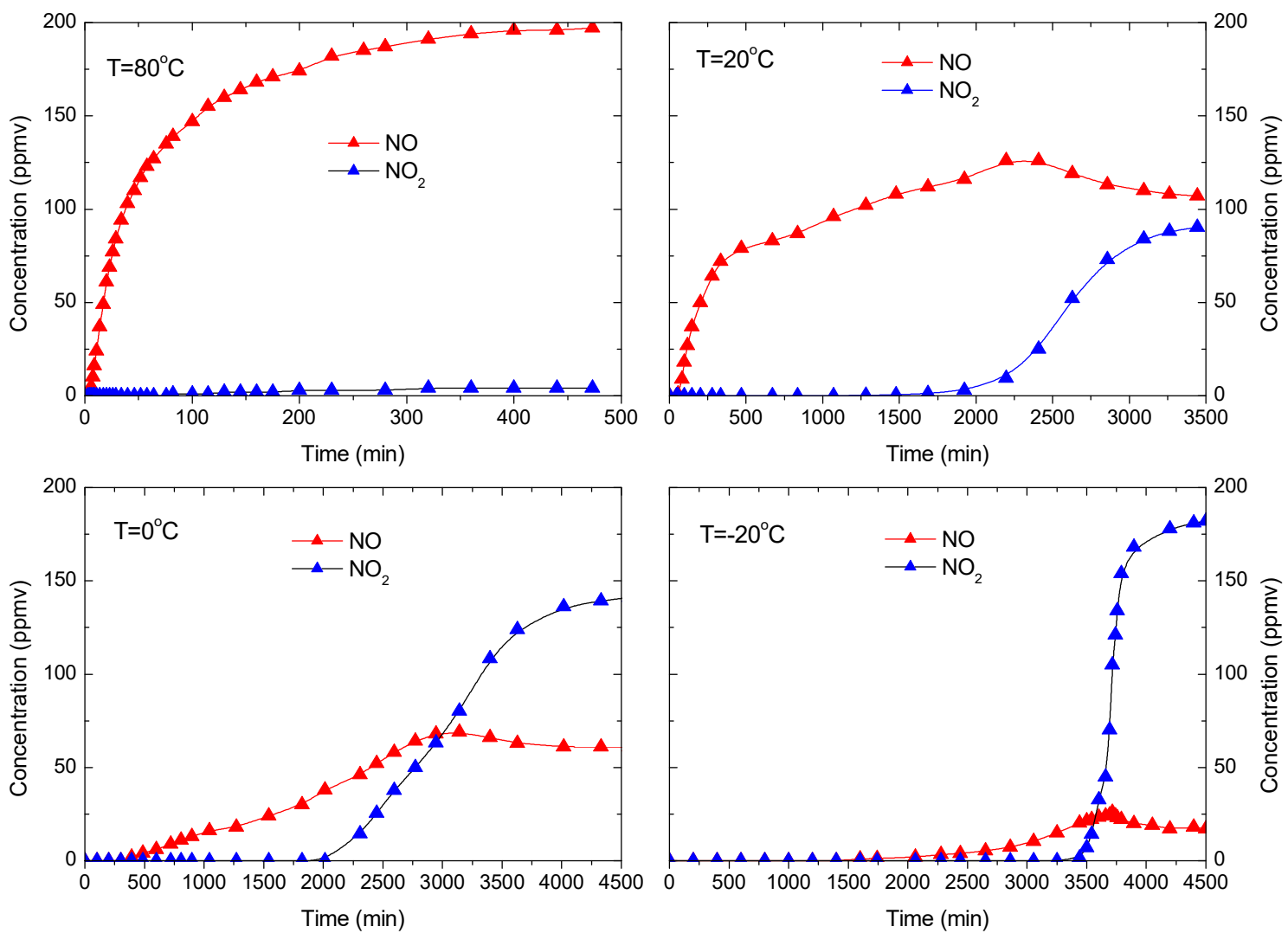

Figure 7 Adsorption breakthrough curve of $\mathrm{NO}^{-\mathrm{O}_{2}}$ co-adsorption at various temperatures $\left(\mathrm{NO}=200 \mathrm{ppmv}, \mathrm{O}_{2}=6 \mathrm{v} \%\right.$, space velocity $\left.=5000 \mathrm{~h}^{-1}\right)$
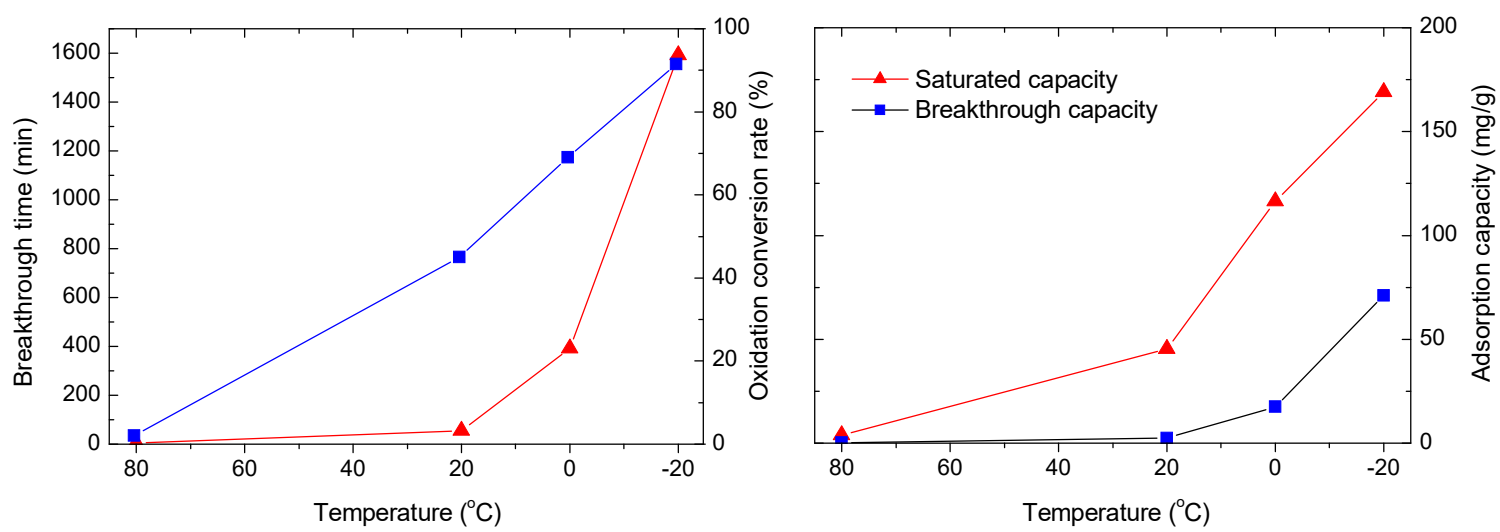

Figure 8 Breakthrough time, oxidation conversion rate (left) and adsorption capacity (right) of $\mathrm{NO}^{-\mathrm{O}_{2}}$ coadsorption at various temperatures $\left(\mathrm{NO}=200 \mathrm{ppmv}, \mathrm{O}_{2}=6 \mathrm{v} \%\right.$, space velocity $\left.=5000 \mathrm{~h}^{-1}\right)$

With the presence of oxygen, the catalytic oxidation of NO is significantly enhanced by reducing the temperature. This is in agreement with the study conducted by Guo et al.[22], in which the catalytic oxidation of $\mathrm{NO}$ by oxygen over activated carbon between $30-100^{\circ} \mathrm{C}$ has been investigated. The mechanism of $\mathrm{NO}$ oxidation over activated carbon is complicated, involving both surface reactions and gaseous reactions. The oxidation of gaseous NO by adsorbed oxygen over the activate surface site is believed to be the dominant pathway[24]. 


$$
\begin{aligned}
& 2 \mathrm{C}\left(\mathrm{)}+\mathrm{O}_{2}+2 \mathrm{C}(\mathrm{O})\right. \\
& \mathrm{C}(\mathrm{O})+\mathrm{NO} \rightarrow \mathrm{C}-\mathrm{NO}_{2} \text { or } \mathrm{C}-\mathrm{ONO} \rightarrow \mathrm{C}+\mathrm{NO}_{2}
\end{aligned}
$$

where $C($ ) represents the activated carbon with active surface site. Based on reaction (6), the oxidation reaction rate can be calculated by the following equation:

$$
\frac{d\left[\mathrm{NO}_{2}\right]}{d t}=k(T)[\mathrm{C}(\mathrm{O})] \times[\mathrm{NO}]
$$

Temperature can impact the oxidation reactions in many ways. First of all, the physisorption of oxygen over activated carbon is enhanced and the concentration of $\mathrm{C}(\mathrm{O})$ is increased by reducing adsorbing temperature[26]. Secondly, the rate constant $k(T)$ of NO oxidation increases with decreasing temperature[27].

In fact, most of the studies on the catalytic oxidation of $\mathrm{NO}$ over activated carbon have a motivation to convert $\mathrm{NO}$ to $\mathrm{NO}_{2}$ which can be scrubbed by alkali solutions. Although some of the studies has revealed that the presence of oxygen can significantly increase the adsorbability of $\mathrm{NO}$ and decreasing temperature has a positive affect on the adsorbability [28, 29], it is still considered unfeasible to remove NO from flue gas by adsorption due to the slow adsorption rate. Unlike the adsorption of $\mathrm{SO}_{2}$ which is fast (breakthrough capacity is quite close to the saturated capacity)[7], the co-adsorption of $\mathrm{NO}-\mathrm{O}_{2}$ is slow at above room temperatures since it is limited by the oxidation reaction rate. As shown in Fig. 7, NO breakthrough the adsorption bed very fast but take a pretty long period to reach saturation adsorption at $80^{\circ} \mathrm{C}$ and $20^{\circ} \mathrm{C}$, and the breakthrough adsorption capacity is only a very small fraction of the saturated adsorption capacity.

However, both the adsorption rate and capacity are extraordinary increased when temperature is further extended to below room temperatures. As shown in Fig. 8 and Tab.1, the breakthrough time and breakthrough adsorption capacity at $-20^{\circ} \mathrm{C}$ is about 456 times of that at $80^{\circ} \mathrm{C}$, and 28 times of that at $20^{\circ} \mathrm{C}$. At lower temperatures, the breakthrough capacity takes a much larger portion of the saturated capacity, representing a much faster adsorption rate and reaction rate. In fact, the breakthrough adsorption capacity of $\mathrm{NO}$ at 0 and $-20^{\circ} \mathrm{C}$ has a magnitude comparable with $\mathrm{SO}_{2}$ adsorption[7], therefore removal of $\mathrm{NO}$ from flue gas by adsorption is feasible at these conditions.

To further investigate the NO- $\mathrm{O}_{2}$ co-adsorption at cold temperatures, the breakthrough curves at 6 selected cross sections of the adsorption bed are observed, which is achieved by conducting 6 experiments at the same temperature with different loaded activated carbon, as shown in Fig. 9. The breakthrough time, adsorption capacity and oxidation conversion rate are given in Tab.2. Results indicate that the oxidation conversion rate increases along the axial direction of the adsorption bed. As shown in Fig.10, at each cross section of the adsorption bed, a stable $\mathrm{NO}-\mathrm{NO}_{2}$ equilibrium is formed both in the gas phase and the adsorption surface. Therefore the $\mathrm{NO}-\mathrm{O}_{2}$ co-adsorption mechanism involves the adsorption of both $\mathrm{NO}$ and $\mathrm{NO}_{2}$ over activated carbon. Since $\mathrm{NO}_{2}$ is a much more adsorbable species than $\mathrm{NO}[30]$, the adsorption capacity increases with the increasing $\mathrm{NO}_{2}$ concentration along the axial direction of activated carbon bed, as shown in Fig.10. At the inlet surface of adsorption bed, theoretically only NO adsorption exists. This is quite different with the adsorption of $\mathrm{SO}_{2}$ which has an uniform adsorption capacity along the adsorption bed. Due to this distinct characteristics, it should be noted that the adsorption capacity given in Fig.10 is average adsorption capacity of a specific volume of activated carbon. The real adsorption capacity at each cross section should be much larger than the average value.

Based on the above analysis, it is now quite clear why the breakthrough time and adsorption capacity of NO$\mathrm{O}_{2}$ co-adsorption increases dramatically when the temperature is reduced to below room temperatures. At cold temperatures, the catalytic oxidation of $\mathrm{NO}$ is fastened, therefore the breakthrough time and breakthrough adsorption capacity are largely increased. In addition, the adsorption capacity of $\mathrm{NO}_{2}$ increases significantly at cold temperatures, leading to prominent increase of saturated adsorption capacity. 

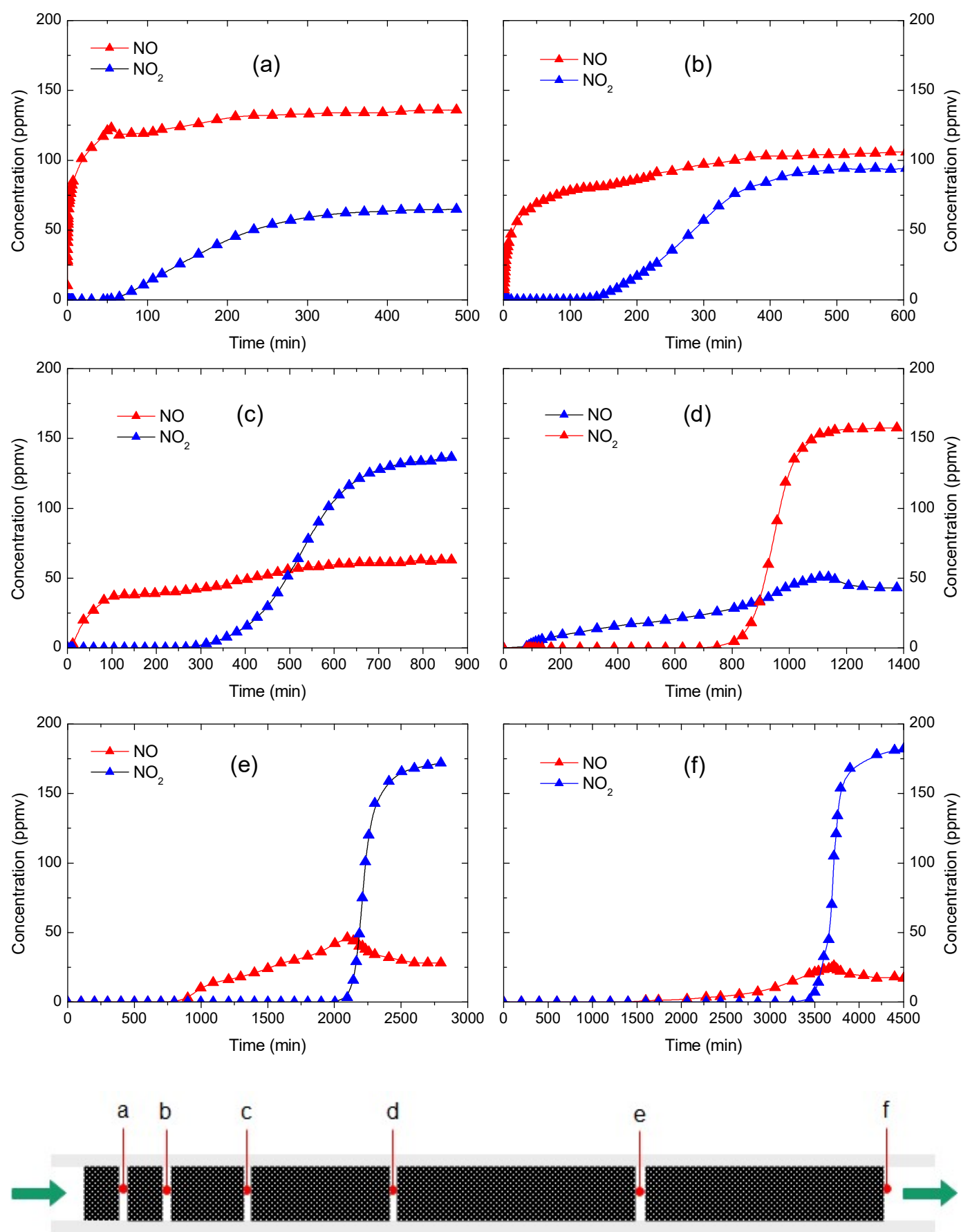

adsorption bed

Figure 9 Adsorption breakthrough curve of $\mathrm{NO}-\mathrm{O}_{2}$ co-adsorption at various cross sections of adsorption bed: (a) $120000 \mathrm{~h}^{-1}$, (b) $60000 \mathrm{~h}^{-1}$, (c) $30000 \mathrm{~h}^{-1}$, (d) $15000 \mathrm{~h}^{-1}$, (e) $7500 \mathrm{~h}^{-1}$ and (f) $5000 \mathrm{~h}^{-1}$

$\left(\mathrm{NO}=200 \mathrm{ppmv}, \mathrm{O}_{2}=6 \mathrm{v} \%, \mathrm{~T}=-20^{\circ} \mathrm{C}\right)$ 

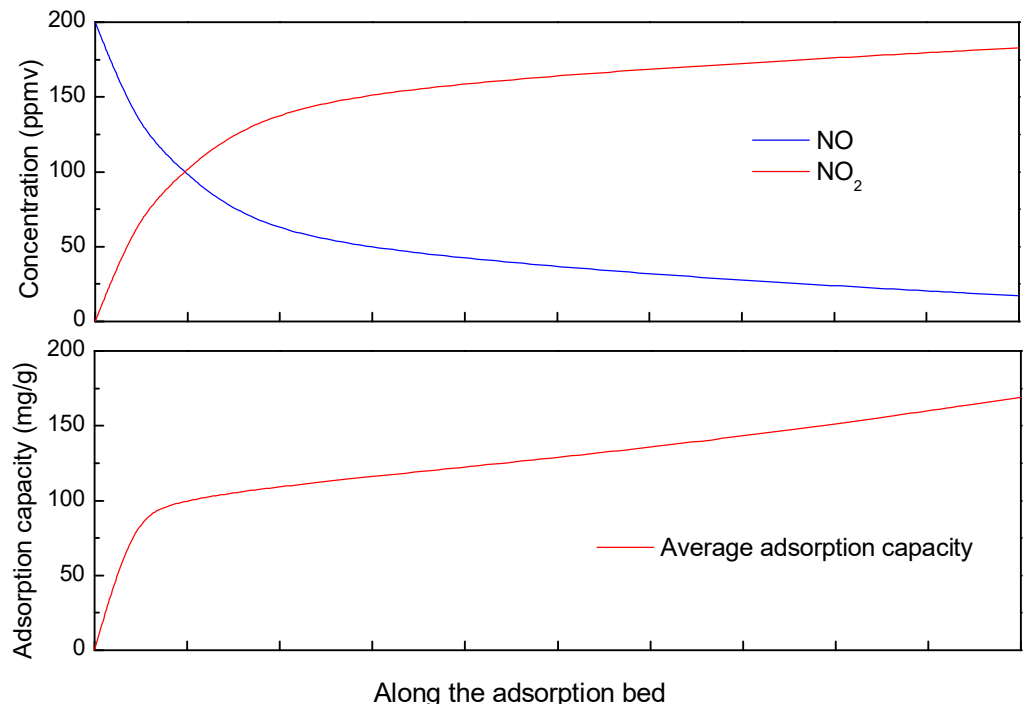

Figure 10 Oxidation and adsorption characteristics of $\mathrm{NO}-\mathrm{O}_{2}$ along activated carbon bed $\left(\mathrm{NO}=200 \mathrm{ppmv}, \mathrm{O}_{2}=6 \mathrm{v} \%, \mathrm{~T}=-20^{\circ} \mathrm{C}\right)$

Table 2 Adsorption characteristics of $\mathrm{NO}-\mathrm{O}_{2}$ at various $\mathrm{CAC}$ load $\left(\mathrm{NO}=200 \mathrm{ppmv}, \mathrm{O}_{2}=6 \mathrm{v} \%\right.$, space velocity $\left.=5000 \mathrm{~h}^{-1}\right)$

\begin{tabular}{|c|c|c|c|c|c|}
\hline \multirow{2}{*}{ Mass of CAC, $\mathrm{g}$} & \multirow{2}{*}{ Space velocity, $\mathrm{h}^{-1}$} & \multicolumn{4}{|c|}{$\mathrm{NO}^{-} \mathrm{O}_{2}$ adsorption } \\
\cline { 3 - 6 } & & $t_{b}, \mathrm{~min}$ & $A_{b}, \mathrm{mg} / \mathrm{g}$ & $A_{s}, \mathrm{mg} / \mathrm{g}$ & $\eta\left(\mathrm{NO}_{2}\right), \%$ \\
\hline 0.25 & 120000 & 0.01 & 0.011 & 88.091 & 32.0 \\
\hline 0.5 & 60000 & 0.44 & 0.236 & 98.476 & 47.0 \\
\hline 1 & 30000 & 10.86 & 2.909 & 107.356 & 68.5 \\
\hline 2 & 15000 & 88.42 & 11.841 & 118.259 & 78.5 \\
\hline 4 & 7500 & 973.18 & 65.169 & 138.999 & 86.0 \\
\hline 6 & 5000 & 1591.75 & 71.061 & 169.142 & 91.5 \\
\hline
\end{tabular}

\subsection{Adsorption of $\mathrm{SO}_{2}$}

The adsorption of $\mathrm{SO}_{2}$ over activated carbon at cold temperatures is also studied. The impact of temperature on adsorption of $\mathrm{SO}_{2}$ is shown in Fig.11. The breakthrough time and saturated adsorption capacity is given in Tab.3. Results show that reducing the temperature from 80 to $-20^{\circ} \mathrm{C}$, the breakthrough time and adsorption capacity has increased by about 13 and 10 times, respectively. $\mathrm{SO}_{2}$ adsorption over activated carbon is fast and the breakthrough adsorption capacity is quite close to the saturated adsorption capacity. The breakthrough curve has a sharp slope which is quite different with that of $\mathrm{NO}$ adsorption.

The impact of $\mathrm{O}_{2}, \mathrm{CO}_{2}$ and $\mathrm{H}_{2} \mathrm{O}$ on the adsorption of $\mathrm{SO}_{2}$ at various temperatures are also investigated. As shown in Tab.3, the presence of oxygen has a slight improvement of $\mathrm{SO}_{2}$ adsorption due to the catalytic oxidation over activated carbon. The presence of $\mathrm{CO}_{2}$ in the opposite has a negative impact on the $\mathrm{SO}_{2}$ adsorption due to the occupation of active carbon surface. The presence of $\mathrm{H}_{2} \mathrm{O}$ and $\mathrm{O}_{2}$ can enhance the adsorption of $\mathrm{SO}_{2}$ through $\mathrm{H}_{2} \mathrm{SO}_{4}$ adsorption[7]. 


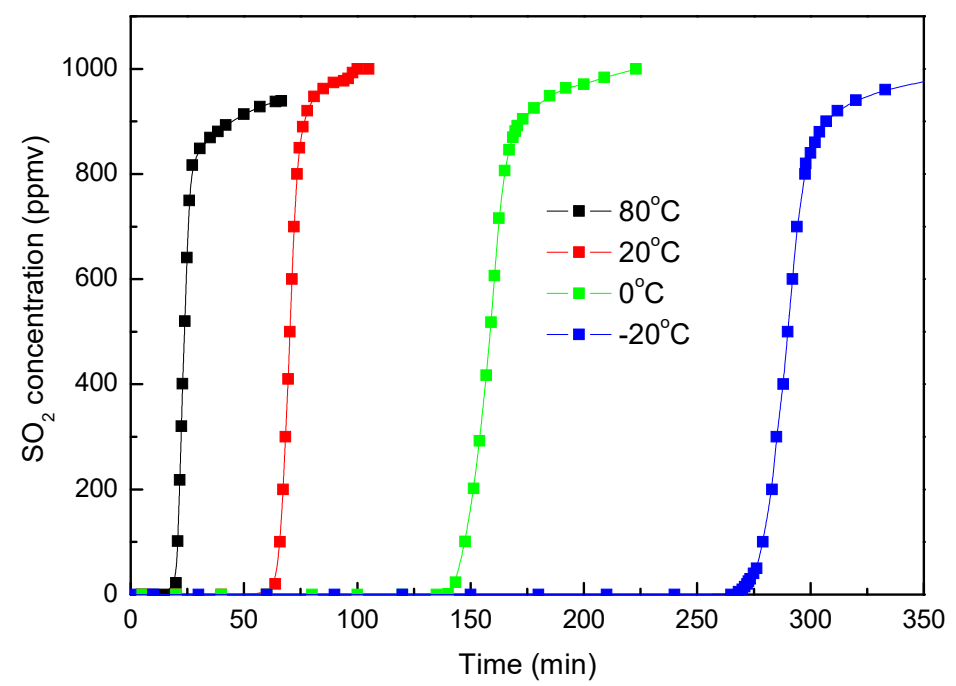

Figure 11 Breakthrough curve of $\mathrm{SO}_{2}$ adsorption over $\mathrm{CAC}$ at various temperatures $\left(\mathrm{SO}_{2}=1000 \mathrm{ppmv}, \mathrm{O}_{2}=6 \mathrm{v} \%\right.$, flow rate $=1 \mathrm{~L} / \mathrm{min}$, space velocity $\left.=5000 \mathrm{~h}^{-1}\right)$

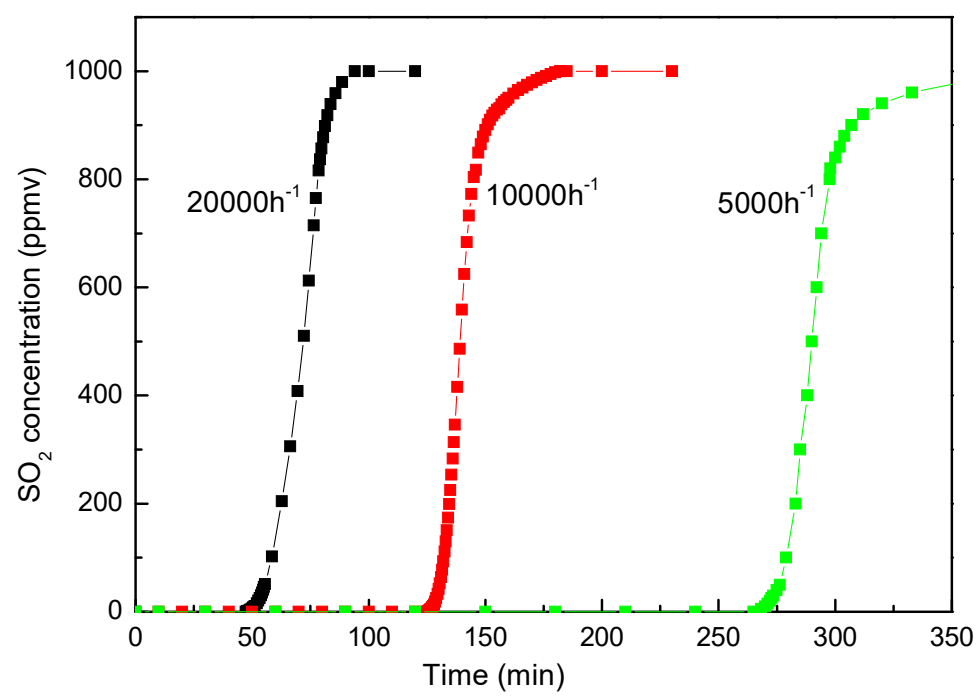

Figure 12 Breakthrough curve of $\mathrm{SO}_{2}$ adsorption over $\mathrm{CAC}$ at various space velocity $\left(\mathrm{SO}_{2}=1000 \mathrm{ppmv}, \mathrm{O}_{2}=6 \mathrm{v} \%, \mathrm{~T}=-20^{\circ} \mathrm{C}\right.$, flow rate $\left.=1 \mathrm{~L} / \mathrm{min}\right)$

Table 3 Adsorption characteristics of $\mathrm{SO}_{2}$ over activated carbon $\left(\mathrm{SO}_{2}=1000\right.$ ppmv, $\mathrm{O}_{2}=6 \mathrm{v} \%, \mathrm{CO}_{2}=12 \mathrm{v} \%$, space velocity $\left.=5000 \mathrm{~h}^{-1}\right)$ $\left(\mathrm{H}_{2} \mathrm{O}: 10 \mathrm{v} \%, 2.3 \mathrm{v} \%\right.$ saturated, $0.6 \%$ saturated and $0.1 \mathrm{v} \%$ saturated at $80,20,0$ and $\left.-20^{\circ} \mathrm{C}\right)$

\begin{tabular}{|c|c|c|c|c|c|c|c|c|}
\hline & \multicolumn{2}{|c|}{$\mathrm{SO}_{2}$} & \multicolumn{2}{c|}{$\mathrm{SO}_{2}-\mathrm{O}_{2}$} & \multicolumn{2}{c|}{$\mathrm{SO}_{2}-\mathrm{O}_{2}-\mathrm{H}_{2} \mathrm{O}$} & \multicolumn{2}{c|}{$\mathrm{SO}_{2}-\mathrm{CO}_{2}$} \\
\hline Temperature, ${ }^{\circ} \mathrm{C}$ & $t_{b}, \mathrm{~min}$ & $A_{s}, \mathrm{mg} / \mathrm{g}$ & $t_{b}, \mathrm{~min}$ & $A_{s}, \mathrm{mg} / \mathrm{g}$ & $t_{b}, \mathrm{~min}$ & $A_{s}, \mathrm{mg} / \mathrm{g}$ & $t_{b}, \mathrm{~min}$ & $A_{s}, \mathrm{mg} / \mathrm{g}$ \\
\hline 80 & 19 & 12.87 & 20 & 13.29 & 28 & 18.25 & 18 & 11.89 \\
\hline 20 & 57 & 29.88 & 61 & 33.97 & 62 & 34.32 & 52 & 28.69 \\
\hline 0 & 130 & 67.72 & 138 & 76.40 & 138 & 73.02 & 109 & 58.74 \\
\hline-20 & 235 & 123.11 & 265 & 140.32 & 269 & 140.17 & 188 & 108.27 \\
\hline
\end{tabular}


The impact of space velocity of CAC load on the adsorption of $\mathrm{SO}_{2}$ is shown in Fig. 12. The breakthrough time is doubled when the CAC load is doubled. This indicates that the adsorption capacity $(\mathrm{mg} / \mathrm{g} \mathrm{CAC})$ is irrelevant with space velocity and is a constant value at certain temperature and partial pressure of $\mathrm{SO}_{2}$. This is also quite different with the adsorption capacity of $\mathrm{NO}$ (with the presence of $\mathrm{O}_{2}$ ) which increases along the adsorption bed as shown in Fig. 10.

The adsorption process of $\mathrm{SO}_{2}$ and $\mathrm{NO}$ with the presence of oxygen over activated carbon is illustrated in Fig.13. There are three regions during the $\mathrm{SO}_{2}$ adsorption process (upleft). In the saturated region, an equilibrium of $\left[\mathrm{SO}_{2}(\mathrm{~g}), \mathrm{SO}_{2}(\mathrm{a})\right]$ is established. Where $(\mathrm{g})$ present gaseous phase and (a) represent adsorbed phase. In the adsorption region, $\mathrm{SO}_{2}(\mathrm{~g})$ is being adsorbed and converted to $\mathrm{SO}_{2}(\mathrm{a})$. Since the adsorption of $\mathrm{SO}_{2}$ is fast, the adsorption region is within a narrow region. In the fresh carbon region, both $\mathrm{SO}_{2}(\mathrm{~g})$ and $\mathrm{SO}_{2}(\mathrm{a})$ are zero. When the adsorption bed reaches the saturated status (upright), a homogeneous equilibrium of $\mathrm{SO}_{2}(\mathrm{~g})$ and $\mathrm{SO}_{2}$ (a) is established cross the entire adsorption bed. For $\mathrm{NO}+\mathrm{O}_{2}$ adsorption (lower left), due to the catalytic oxidation, equilibriums of $[\mathrm{NO}(\mathrm{g}), \mathrm{NO}(\mathrm{a})]$ and $\left[\mathrm{NO}_{2}(\mathrm{~g}), \mathrm{NO}_{2}(\mathrm{a})\right]$ co-exist, with increasing $\mathrm{NO}_{2}$ and decreasing $\mathrm{NO}$ along the bed. Since the adsorption of $\mathrm{NO}$ is almost neglectable compared with $\mathrm{NO}_{2}$, the total adsorption capacity increases along the adsorption bed in the saturated region. In the adsorption region, the remaining NO is further oxidized to $\mathrm{NO}_{2}$ and adsorbed. Since the adsorption rate is limited by oxidation rate, the adsorption of $\mathrm{NO}+\mathrm{O}_{2}$ is much slower than $\mathrm{SO}_{2}$ and the adsorption region is much wider. When it is reaches saturated status, equilibrium of $[\mathrm{NO}(\mathrm{g})$, $\mathrm{NO}(\mathrm{a})]$ with decreasing partial pressure and equilibrium of $\left[\mathrm{NO}_{2}(\mathrm{~g}), \mathrm{NO}_{2}(\mathrm{a})\right]$ with increasing partial pressure are established along the adsorption bed.
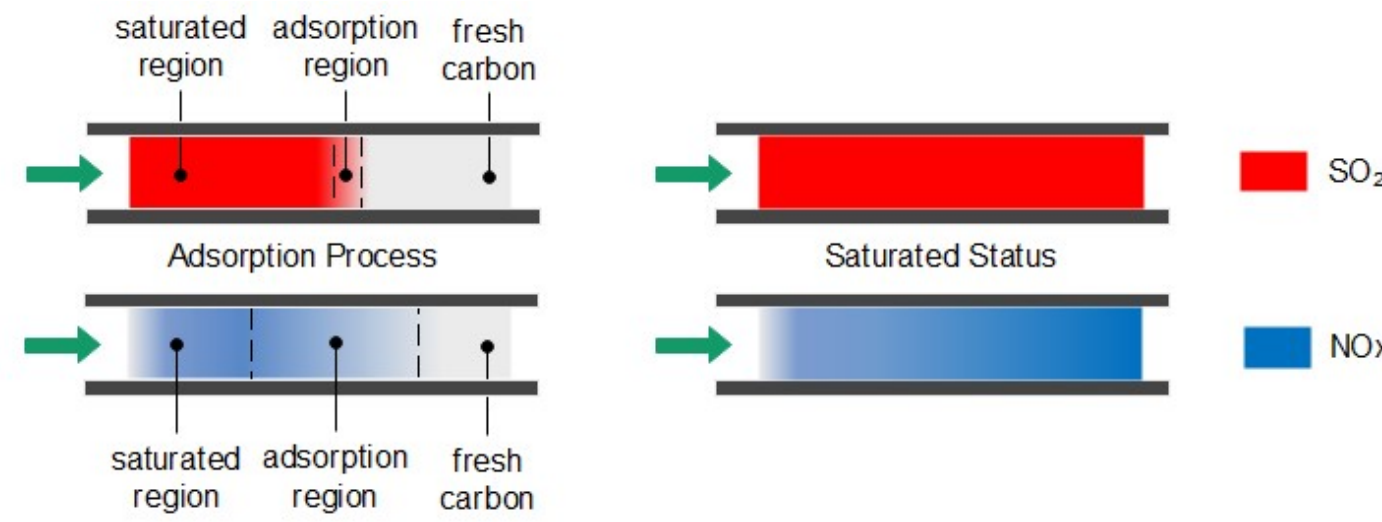

Saturated Status

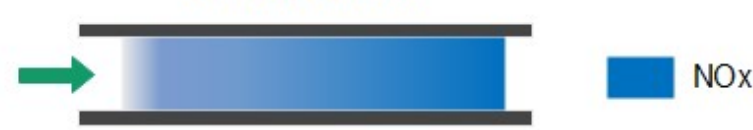

Figure 13 Adsorption process of $\mathrm{SO}_{2}$ and $\mathrm{NO}$ with presence of oxygen over activated carbon

\subsection{Pilot test}

The pilot test platform is built in Huaneng Yueyang Power Plant and is accomplished in Sep. 2020. A detail description of the the process is given in Section 2.3. A picture of the pilot test platform is shown in Fig. 14. A preliminary low-temperature adsorption test is conducted in October. The flue gas flow rate is $3600 \mathrm{Nm}^{3} / \mathrm{h}$ and the operating temperature is $-15 \sim-20^{\circ} \mathrm{C}$. Fig. 15 and 16 shows some of the operating data of a successive $72 \mathrm{hrs}$ test. The inlet flue gas has an $\mathrm{SO}_{2}$ concentration of around $1500-2000 \mathrm{mg} / \mathrm{Nm}^{3}$ and NOx concentration of around $200 \mathrm{mg} / \mathrm{Nm}^{3}$. The concentrations of both $\mathrm{SO}_{2}$ and NOx are reduced to around $1 \mathrm{mg} / \mathrm{Nm}^{3}$ after the adsorber. More tests are undergoing and will be shared as soon as the data are unclassified. In addition, the performance and energy penalty are evaluated by conducting Aspen Plus modeling, and the energy penalty is about $2 \sim 3 \%$ of the total net power generation depending on the ambient temperatures. The detail data of the pilot test and the modeling work will be presented and discussed shortly. 


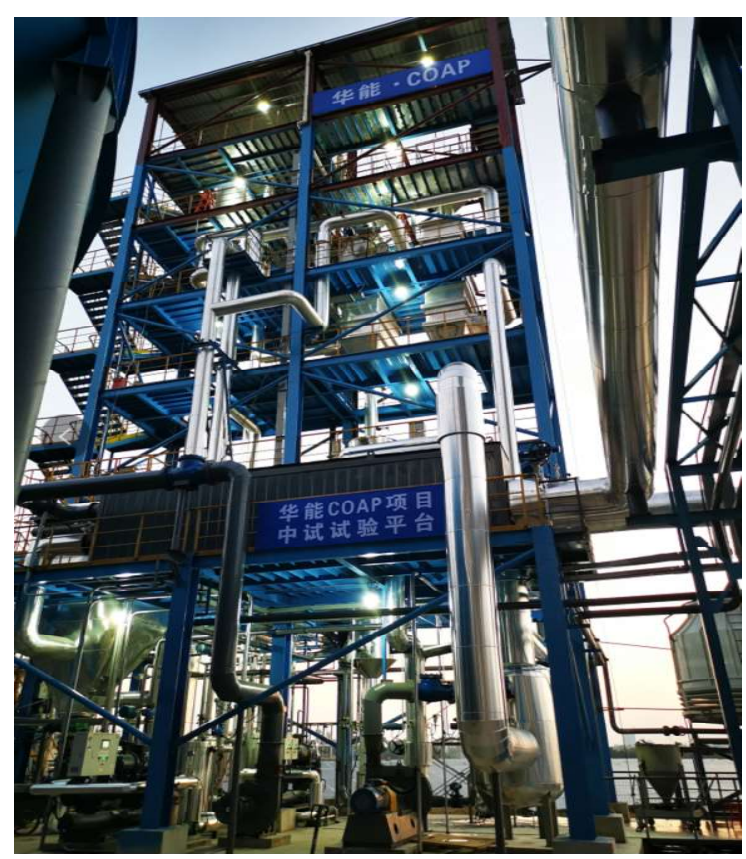

Figure 14 A picture of pilot test platform of low-temperature adsorption desulfurization and denitrification

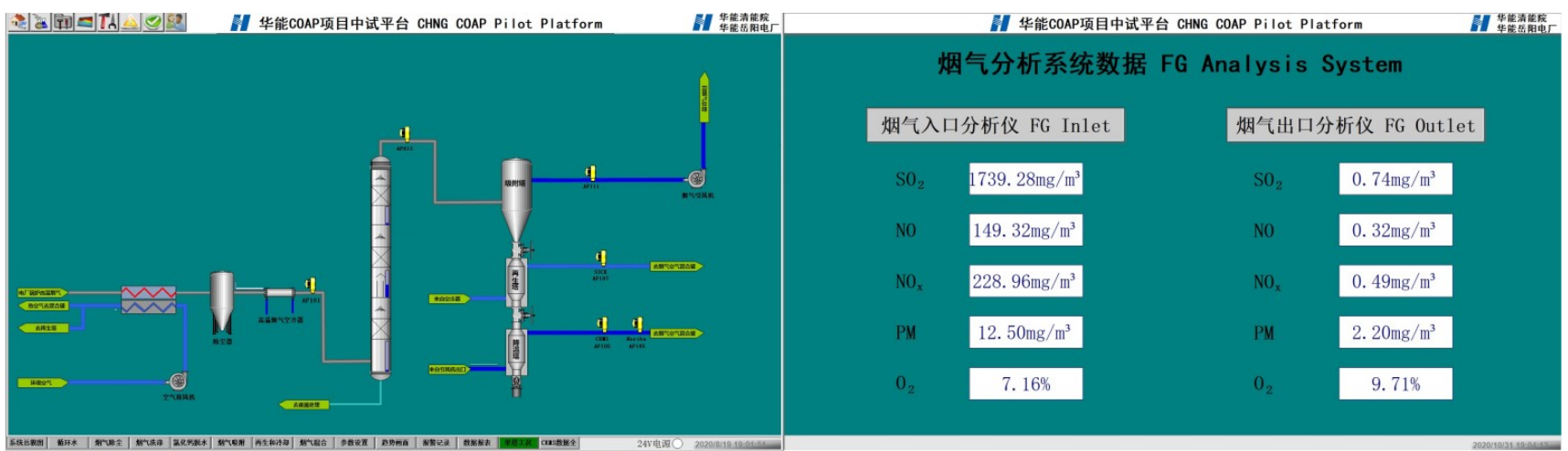

Figure 15 Process diagram and on-line flue gas monitoring and analysis system

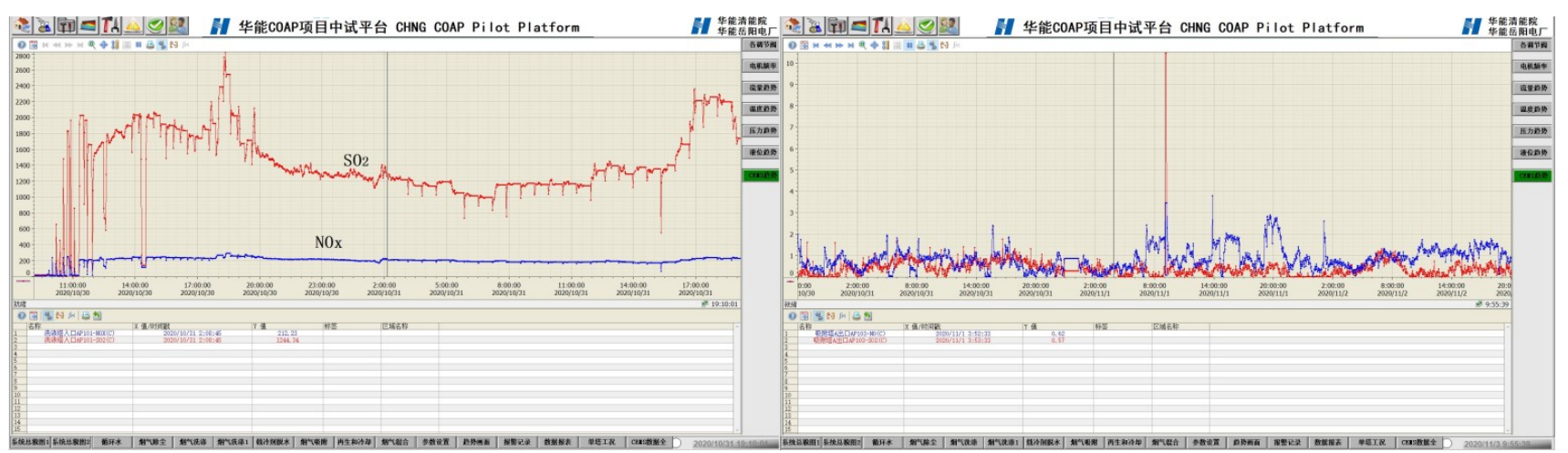

Figure 16 Inlet and outlet concentration of $\mathrm{SO}_{2}$ and $\mathrm{NOx}$ during $72 \mathrm{hrs}$ adsorption performance test 


\section{Conclusion}

In this study, the oxidation and adsorption charateristics of $\mathrm{NO}$ over activated carbon at cold temperatures is investigated. With the presence of oxygen, both the oxidation rate and adsorption of $\mathrm{NO}$ over activated carbon is enhanced significantly at cold tempertures. The breakthrough time of NO increases from 3.45 to 1591.75 minutes when the adsorption temperature decreases from 80 to $-20^{\circ} \mathrm{C}$. At each cross sections along the adsorption bed, NO and $\mathrm{NO}_{2}$ equilibrium is established with decreasing $\mathrm{NO}$ and increasing $\mathrm{NO}_{2}$ along the bed, which leads to a increasing adsorption capacity along the bed. The adsorption of $\mathrm{SO}_{2}$ also increases significantly at cold temperatures. The adsorptoin capacity increases from 12.87 to $123.11 \mathrm{mg} / \mathrm{g}$ when the temperature decreases from 80 to $-20^{\circ} \mathrm{C}$. A novel low-temperature adsorption process is developed to simultaneously remove $\mathrm{SO}_{2}$ and $\mathrm{NOx}$ from fue gas. A pilot scale test platform is built and the low-temperature adsorption process is tested. Near-zero emission of both $\mathrm{SO}_{2}$ and $\mathrm{NOx}$ is achieved during a $72 \mathrm{hrs}$ performance validation test.

\section{Acknowledgement}

This study was supported by the China Huaneng Group (Grant Nos TY-19-HJK01 and TY-19-HJK05) .

\section{Reference}

1. Srivastava, R. and W. Jozewicz, Flue Gas Desulfurization: The State of the Art [J]. Journal of the Air \& Waste Management Association (1995), 2002. 51: p. 1676-88.

2. Wang, E., et al., Review of Advanced Technology of Flue Gas Desulphurization. Advanced Materials Research, 2014. 852: p. 86-91.

3. Guo, L., Y. Shu, and J. Gao, Present and Future Development of Flue Gas Control Technology of DeNO_X in the World. Energy Procedia, 2012. 17: p. 397-403.

4. Boldyreff, B., et al., Combined desulfurization, denitrification and reduction of air toxics using activated coke - 1. Activity of activated coke. Fuel, 1997. 76.

5. Tsuji, K. and I. Shiraishi, Combined desulfurization, denitrification and reduction of air toxics using activated coke - 2. Process applications and performance of activated coke. Fuel, 1997. 76.

6. Olson, D., K. Tsuji, and I. Shiraishi, The Reduction of Gas Phase Air Toxics from Combustion and Incineration Sources Using the MET-Mitsui-BF Activated Coke Process. Fuel Processing Technology, 2000. 65/66: p. 393-405.

7. Sun, F., et al., Mechanism of SO2 adsorption and desorption on commercial activated coke. Korean Journal of Chemical Engineering, 2011. 28: p. 2218-2225.

8. Wang, X., et al., Selective catalytic reduction of NOx by activated carbon. Dongnan Daxue Xuebao (Ziran Kexue Ban)/Journal of Southeast University (Natural Science Edition), 2011. 41: p. 145-149.

9. Zhu, T., et al., Pollutants emission and control for sintering flue gas. 2016. p. 59-74.

10. Jiang, J.-C., X. Jiang, and Z.-S. Yang, Flue Gas Desulfurization and Denitrification by Activated Coke: A Mini-Review. Recent Patents on Chemical Engineering, 2013. 6.

11. Mochida, I., et al., Catalytic activity of coke activated with sulphuric acid for the reduction of nitric oxide. Fuel, 1983. 62: p. 867-868.

12. $\mathrm{Xu}, \mathrm{Z}$., et al., An efficient and sulfur resistant K-modified activated carbon for SCR denitrification compared with acid-and Cu-modified activated carbon. Chemical Engineering Journal, 2020. 395: p. 125047.

13. Zuo, Y., H. Yi, and X. Tang, Metal-Modified Active Coke for Simultaneous Removal of SO 2 and NO x from Sintering Flue Gas. Energy \& Fuels, 2015. 29: p. 377-383. 
14. Mochida, I., et al., Removal of SOx and NOx over activated carbon fibers. Carbon, 2013. 38: p. 227-239.

15. Chengxue, W. and D. Zhenheng, Studies on HZSM-5 zeolite catalysts for desulfurization and denitrification. 2011 International Conference on Consumer Electronics, Communications and Networks, CECNet 2011 - Proceedings, 2011.

16. Penkova, A., et al., FTIR spectroscopic study of low temperature $\mathrm{NO}$ adsorption and $\mathrm{NO}+\mathrm{O} 2$ coadsorption on H-ZSM-5. Langmuir : the ACS journal of surfaces and colloids, 2004. 20: p. 5425-31.

17. Tseng, H., J. Haslbeck, and L. Neal, Evaluation of the NOXSO combined NO/sub x//SOâ flue gas treatment process: process chemistry, reaction kinetics, sorbent performance, process design and cost analysis. Final report. [Alumina substrate impregnated with sodium carbonate]. 2020.

18. Liu, D., et al., Regenerable CuO-Based Adsorbents for Low Temperature Desulfurization Application. Industrial \& Engineering Chemistry Research, 2015. 54: p. 3556-3562.

19. Condon, J., An Overview of Physisorption. 2006. p. 1-27.

20. Fang, Z., X. Yu, and S.-T. Tu, Catalytic oxidation of NO on activated carbons. Energy Procedia, 2019. 158: p. 2366-2371.

21. Dastgheib, S., et al., NO Oxidation by Activated Carbon Catalysts: Impact of Carbon Characteristics, Pressure, and the Presence of Water. ACS Omega, 2020. XXXX.

22. Guo, Z.-C., et al., Catalytic oxidation of NO to NO2 on activated carbon. Energy Conversion and Management, 2001. 42: p. 2005-2018.

23. Sousa, J., M. Pereira, and J. Figueiredo, Catalytic oxidation of NO to NO 2 on N-doped activated carbons. Catalysis Today - CATAL TODAY, 2011. 176: p. 383-387.

24. Xu, X., et al., Method for the Control of NO x Emissions in Long-Range Space Travel. Energy \& fuels : an American Chemical Society journal, 2003. 17: p. 1303-10.

25. Kong, Y. and C. Cha, NOx adsorption on char in presence of oxygen and moisture. Carbon, 1996. 34: p. 1027-1033.

26. Park, D., et al., Equilibrium and kinetics of nitrous oxide, oxygen and nitrogen adsorption on activated carbon and carbon molecular sieve. Separation and Purification Technology, 2019. 223.

27. Tsukahara, H., T. Ishida, and M. Mayumi, Gas-Phase Oxidation of Nitric Oxide: Chemical Kinetics and Rate Constant. Nitric oxide : biology and chemistry / official journal of the Nitric Oxide Society, 1999. 3: p. 191-8.

28. Richter, E., H.-J. Schmidt, and H.-G. Schecker, Adsorption and catalytic reactions of NO and NH3 on activated carbon. Chemical Engineering \& Technology - CHEM ENG TECHNOL, 1990. 13: p. 332-340.

29. Zhang, W.J., et al., Study of NO adsorption on activated carbons. Applied Catalysis B: Environmental, 2008. 83: p. 63-71.

30. Sager, U., et al., Differences between the adsorption of NO2 and NO on modified activated carbon. Gefahrstoffe Reinhaltung der Luft, 2014. 74: p. 181-184. 


\section{Figures}

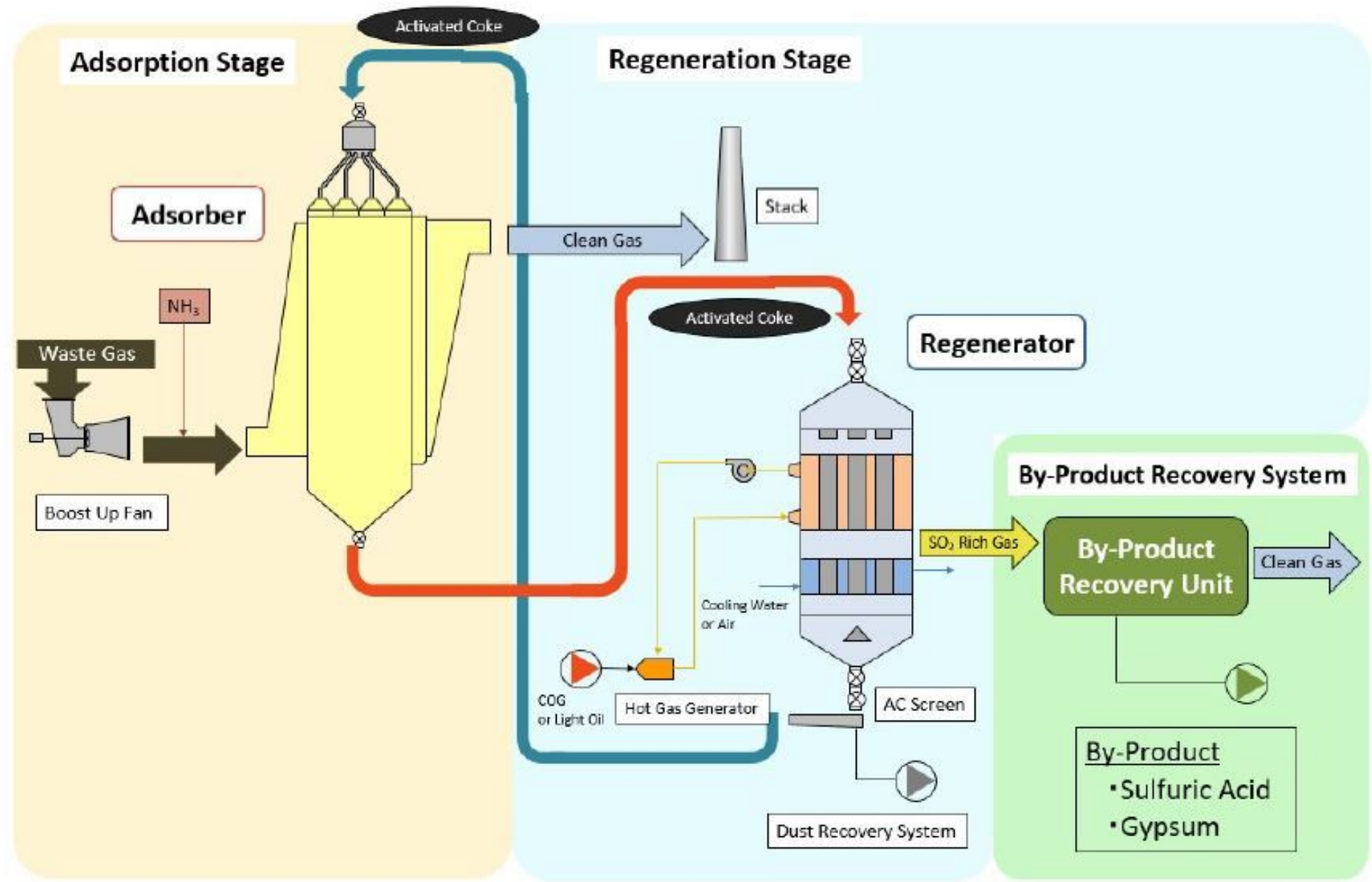

Figure 1

Schematic drawing of the activated coke desulfurization and denitrification process[6] 


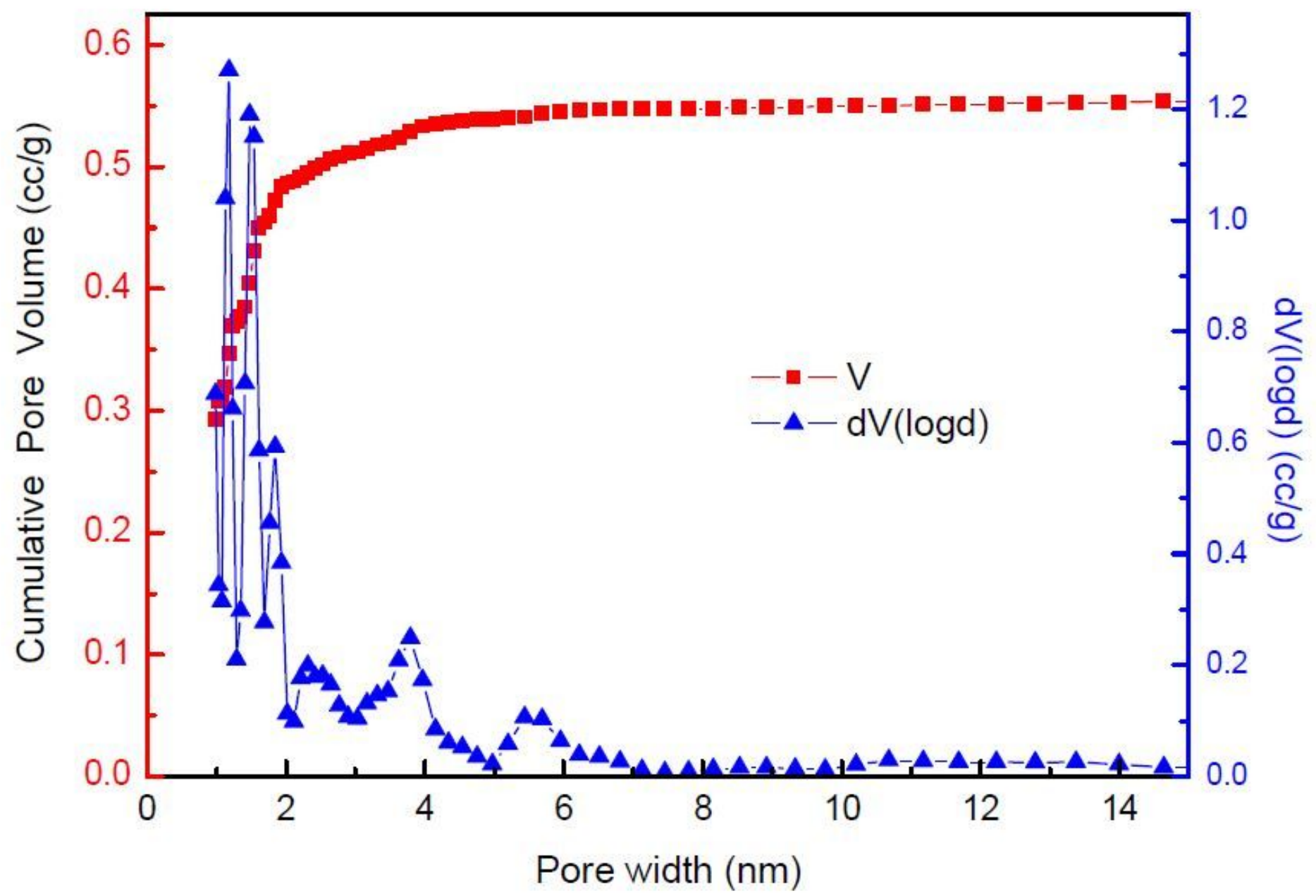

Figure 2

Pore distribution of coconut activated carbon 


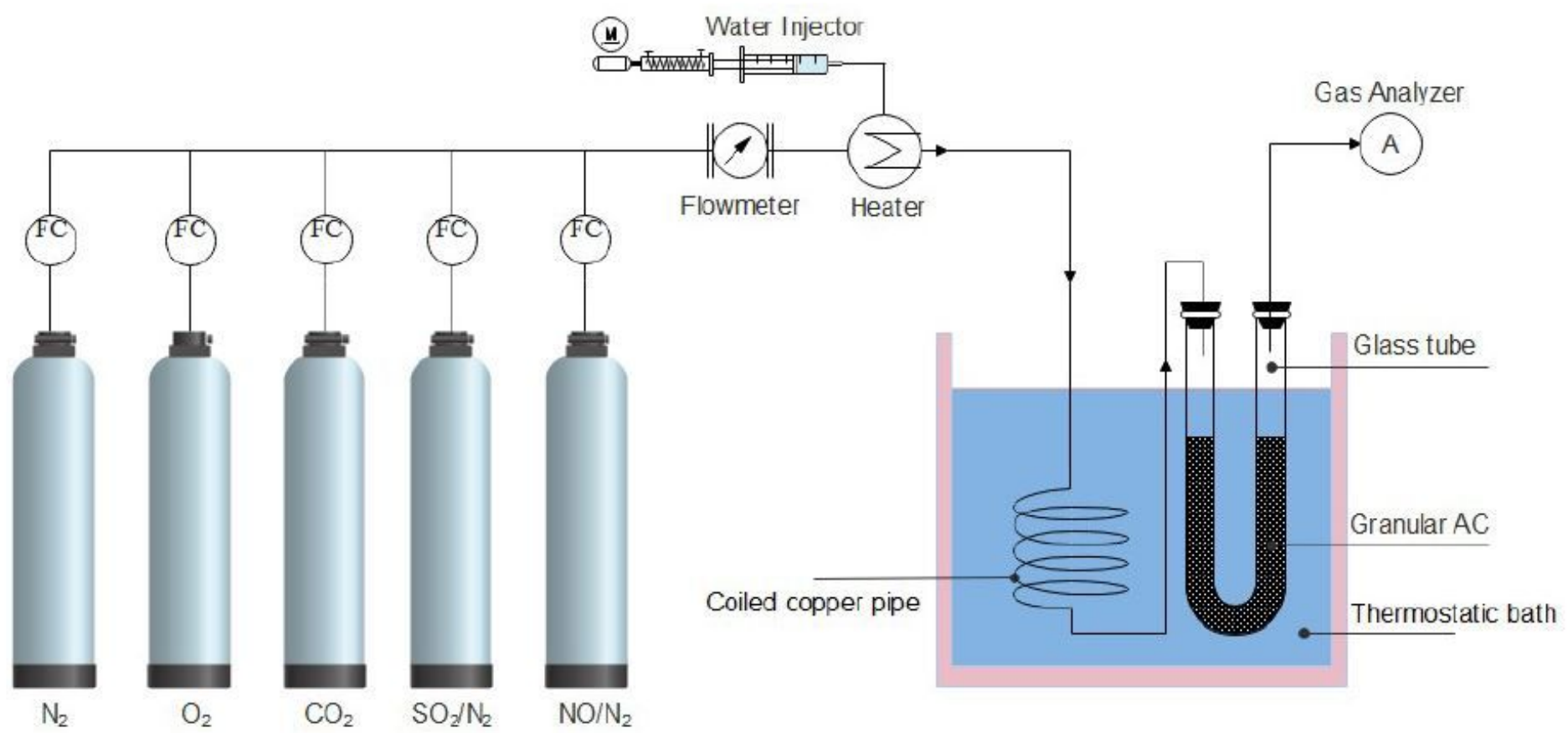

Figure 3

Experimental setup for low-temperature adsorption of SO2 and NO
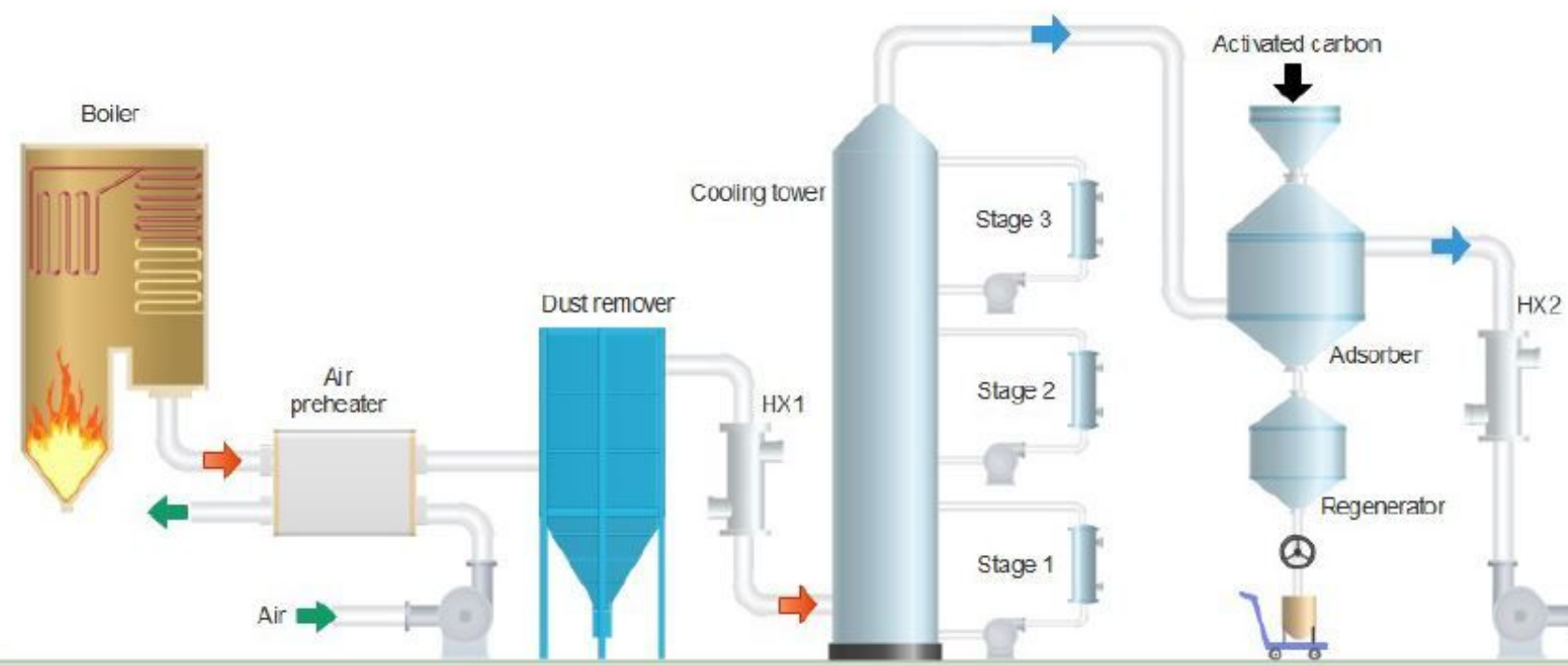

Figure 4

Schematic flowchart of pilot-scale test platform 

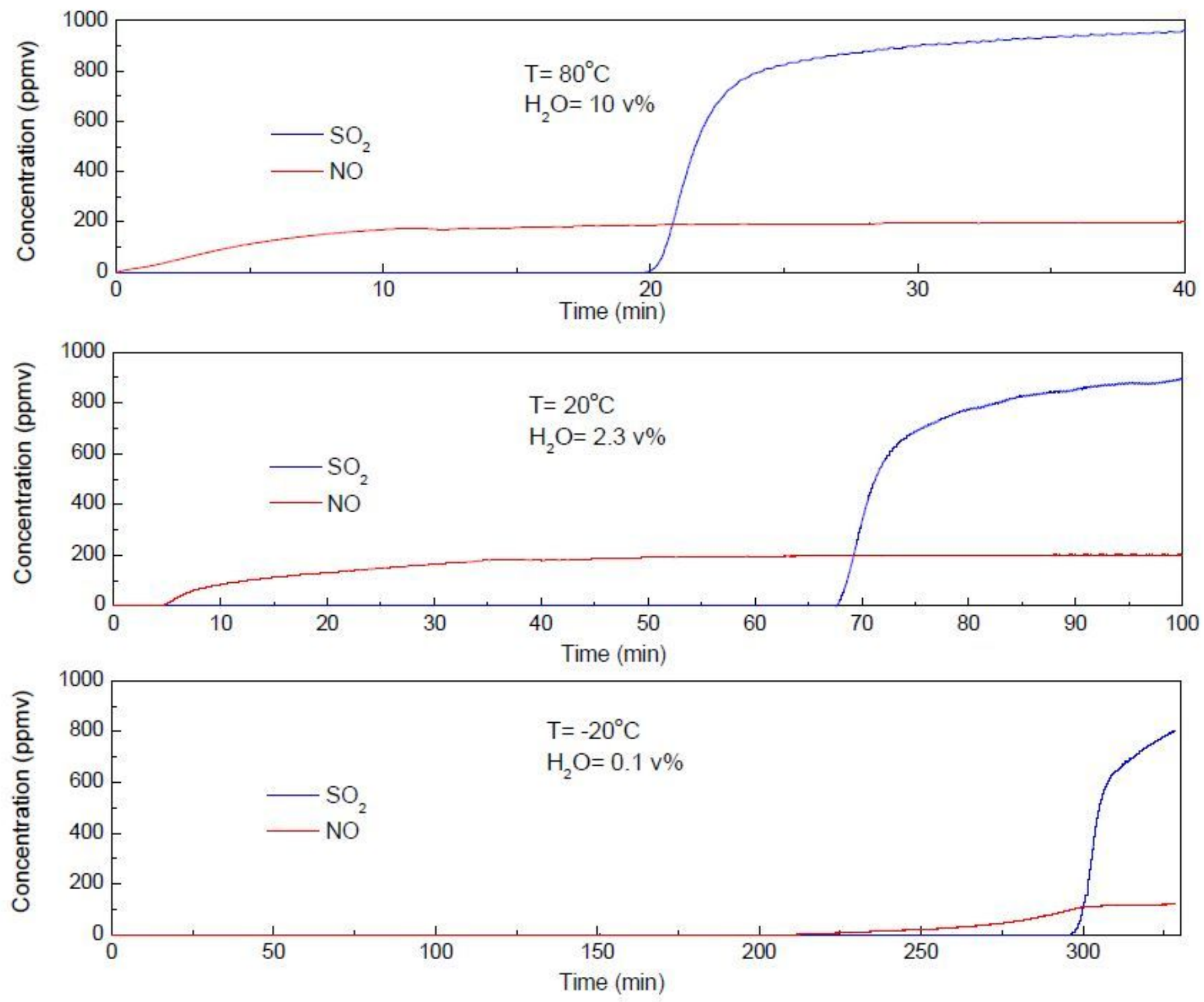

Figure 5

Adsorption breakthrough curves of SO2 and NO adsorption at various temperatures ( $\mathrm{SO} 2=1000 \mathrm{ppmv}$, $\mathrm{NO}=200$ ppmv, O2=6 v\%, CO2=12 v\%, space velocity $=5000 \mathrm{~h}-1$ ) 


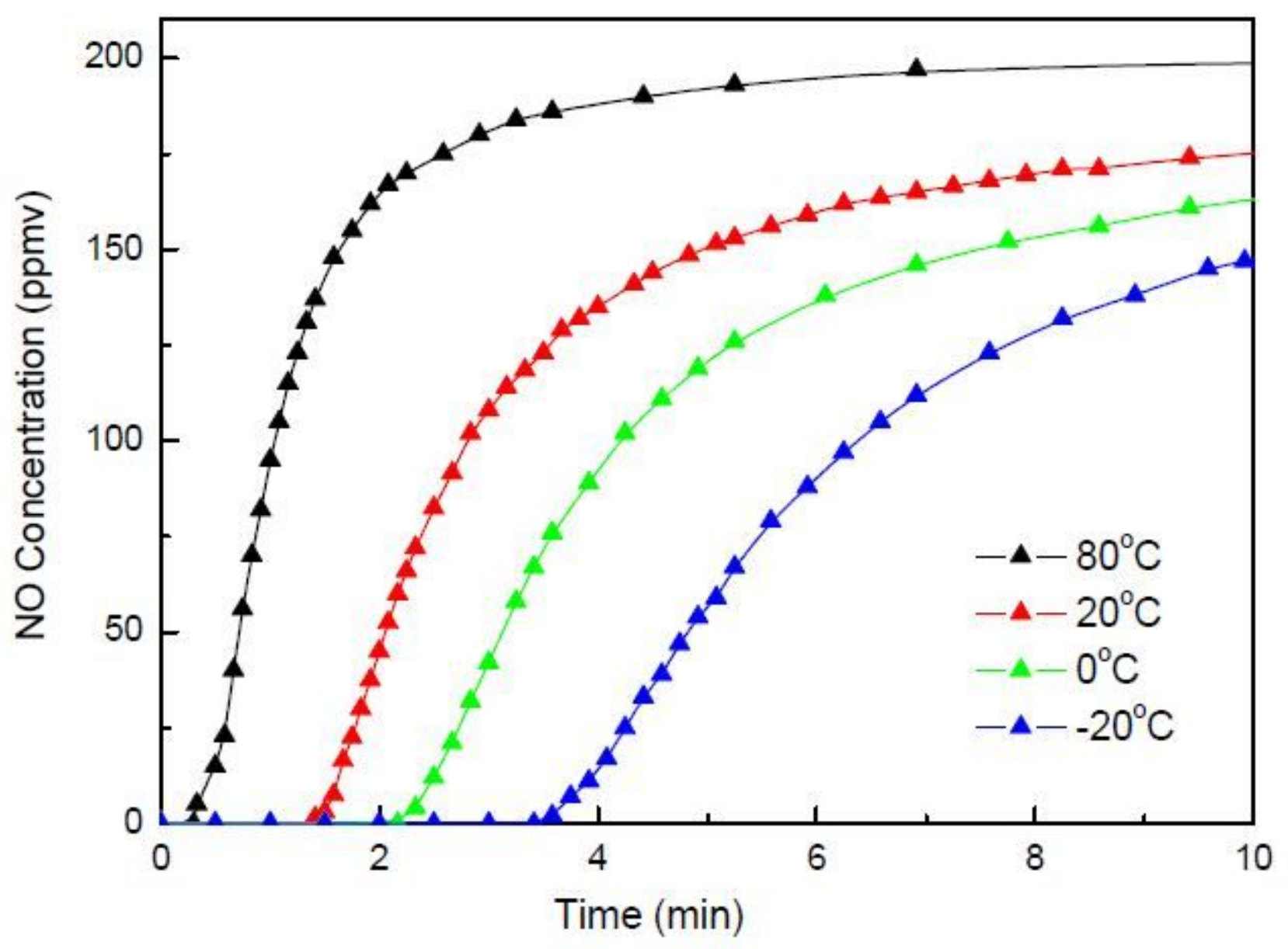

Figure 6

Adsorption breakthrough curve of $\mathrm{NO}$ at various temperatures ( $\mathrm{NO}=200 \mathrm{ppmv}$, space velocity $=5000 \mathrm{~h}-1)$ 

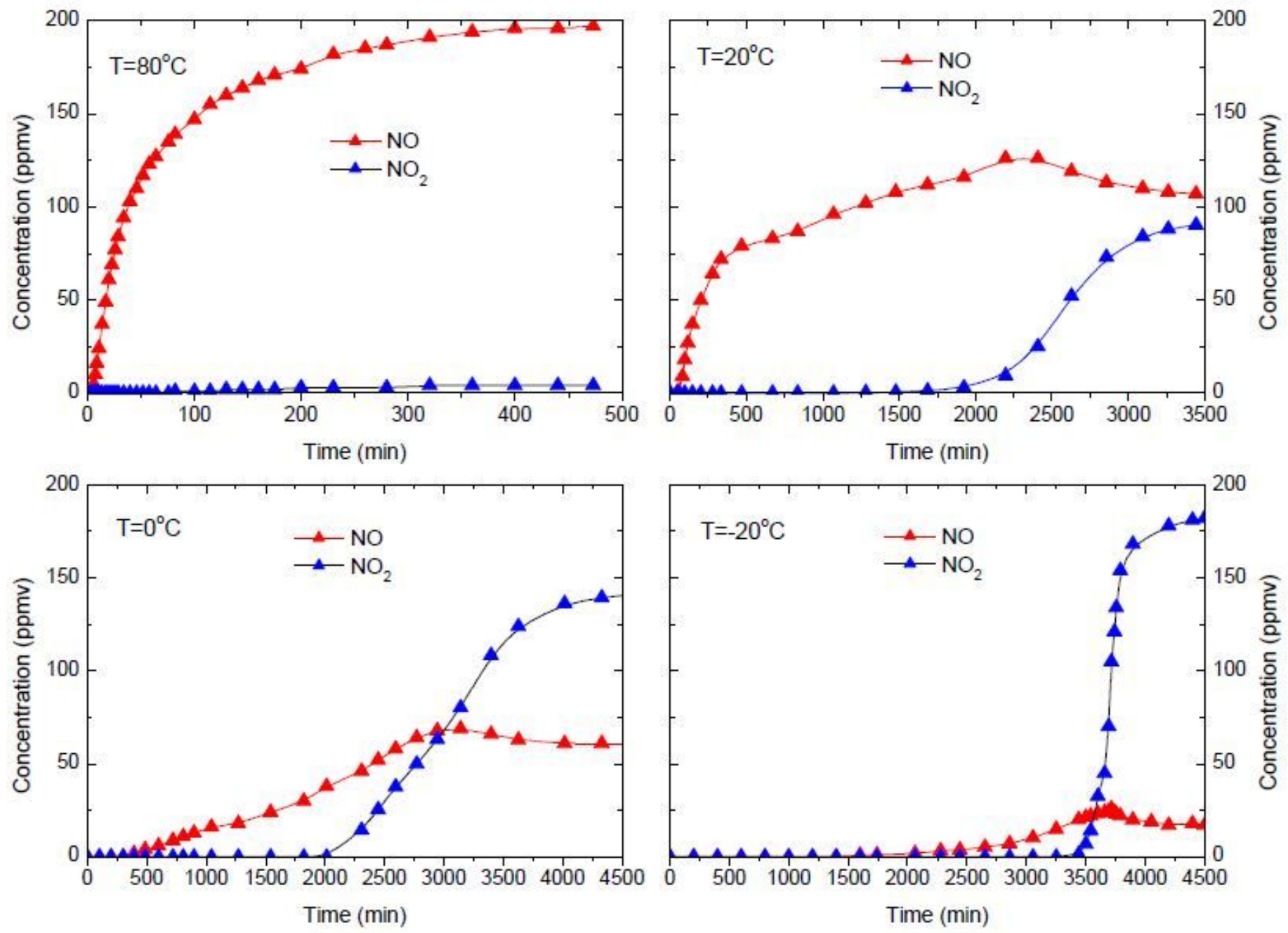

Figure 7

Adsorption breakthrough curve of NO-02 co-adsorption at various temperatures (NO=200ppmv, $02=6 \mathrm{v} \%$, space velocity $=5000 \mathrm{~h}-1$ )
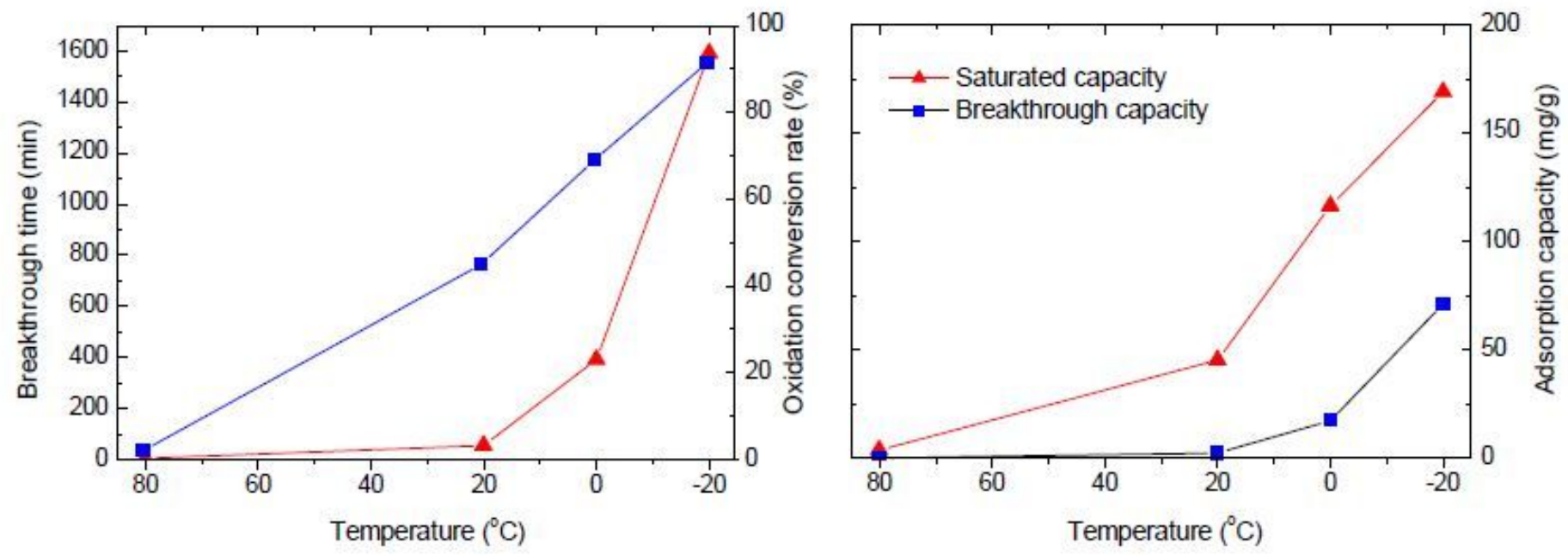

Figure 8 
Breakthrough time, oxidation conversion rate (left) and adsorption capacity (right) of NO-02 coadsorption at various temperatures $(\mathrm{NO}=200 \mathrm{ppmv}, 02=6 \mathrm{v} \%$, space velocity $=5000 \mathrm{~h}-1)$
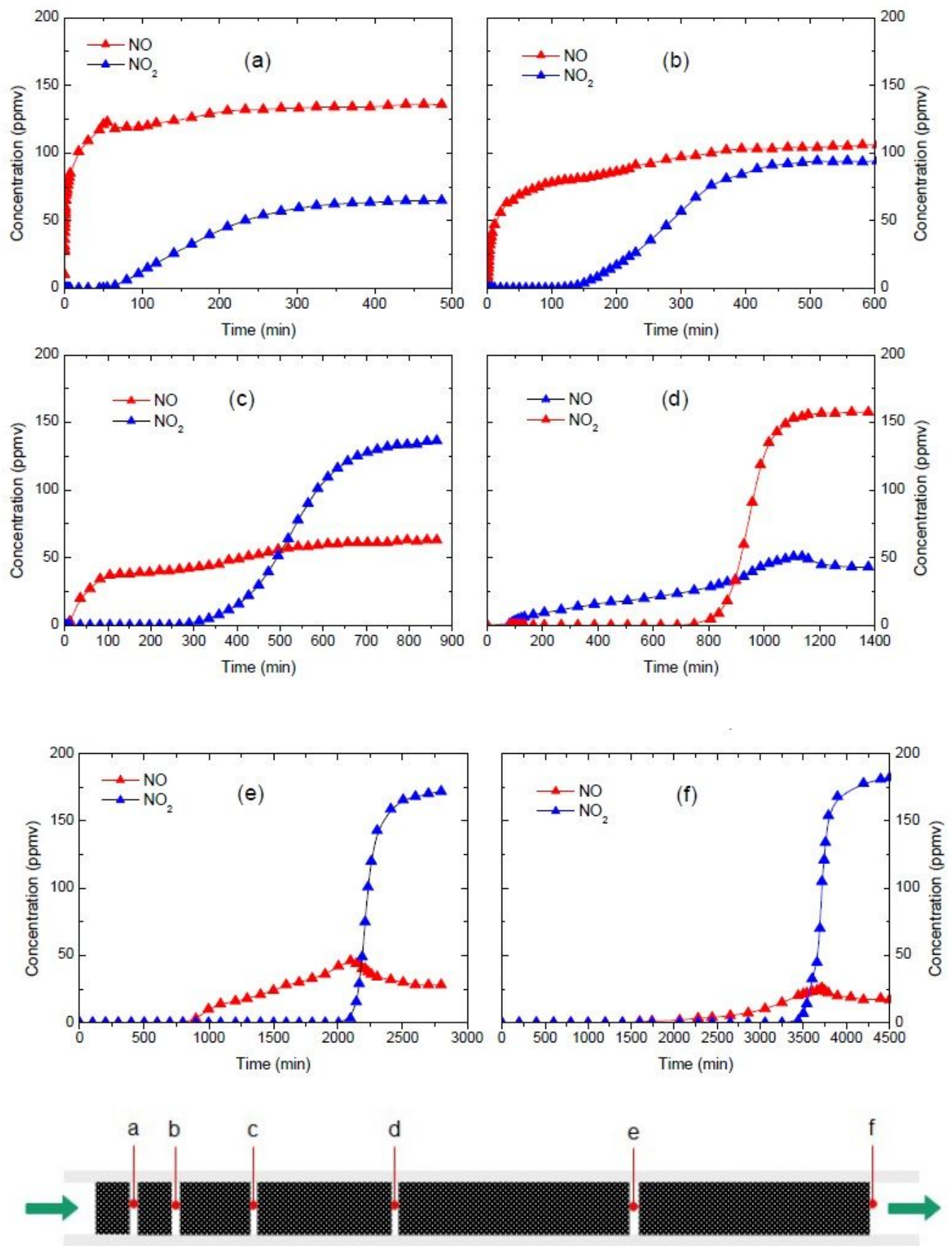

adsorption bed

\section{Figure 9}

Adsorption breakthrough curve of NO-O2 co-adsorption at various cross sections of adsorption bed: (a) 120000 h-1, (b) 60000 h-1, (c) 30000 h-1, (d) 15000 h-1, (e) 7500 h-1 and (f) 5000 h-1 (NO=200ppmv, 02 $=6 \mathrm{v} \%, \mathrm{~T}=-20 \mathrm{Q})$ 

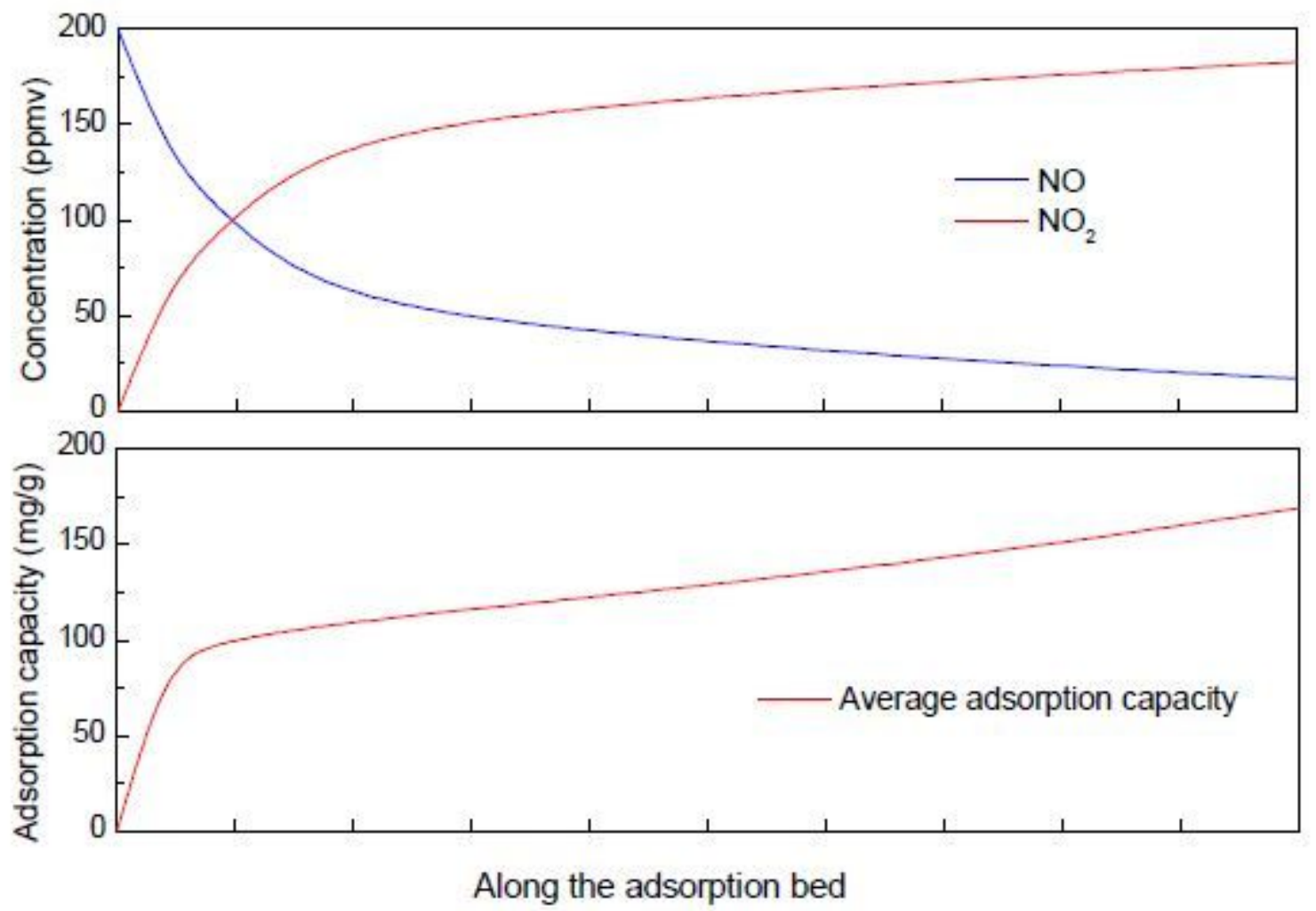

Figure 10

Oxidation and adsorption characteristics of NO-02 along activated carbon bed (NO=200ppmv, $02=6 \mathrm{v} \%$, $\mathrm{T}=-20 \mathrm{Q})$ 


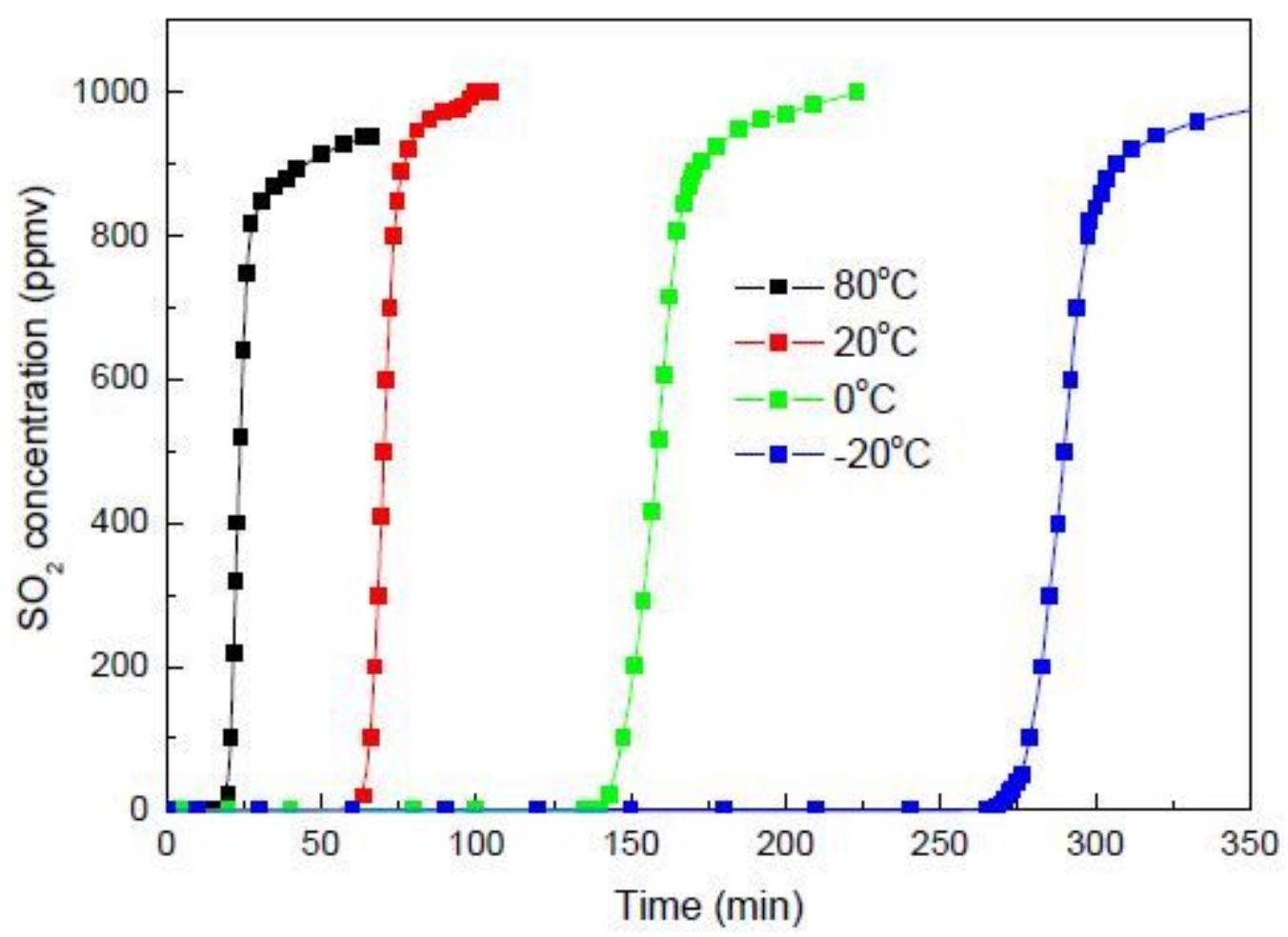

Figure 11

Breakthrough curve of SO2 adsorption over CAC at various temperatures (SO2=1000 ppmv, $02=6 \mathrm{v} \%$, flow rate $=1 \mathrm{~L} / \mathrm{min}$, space velocity $=5000 \mathrm{~h}-1$ )

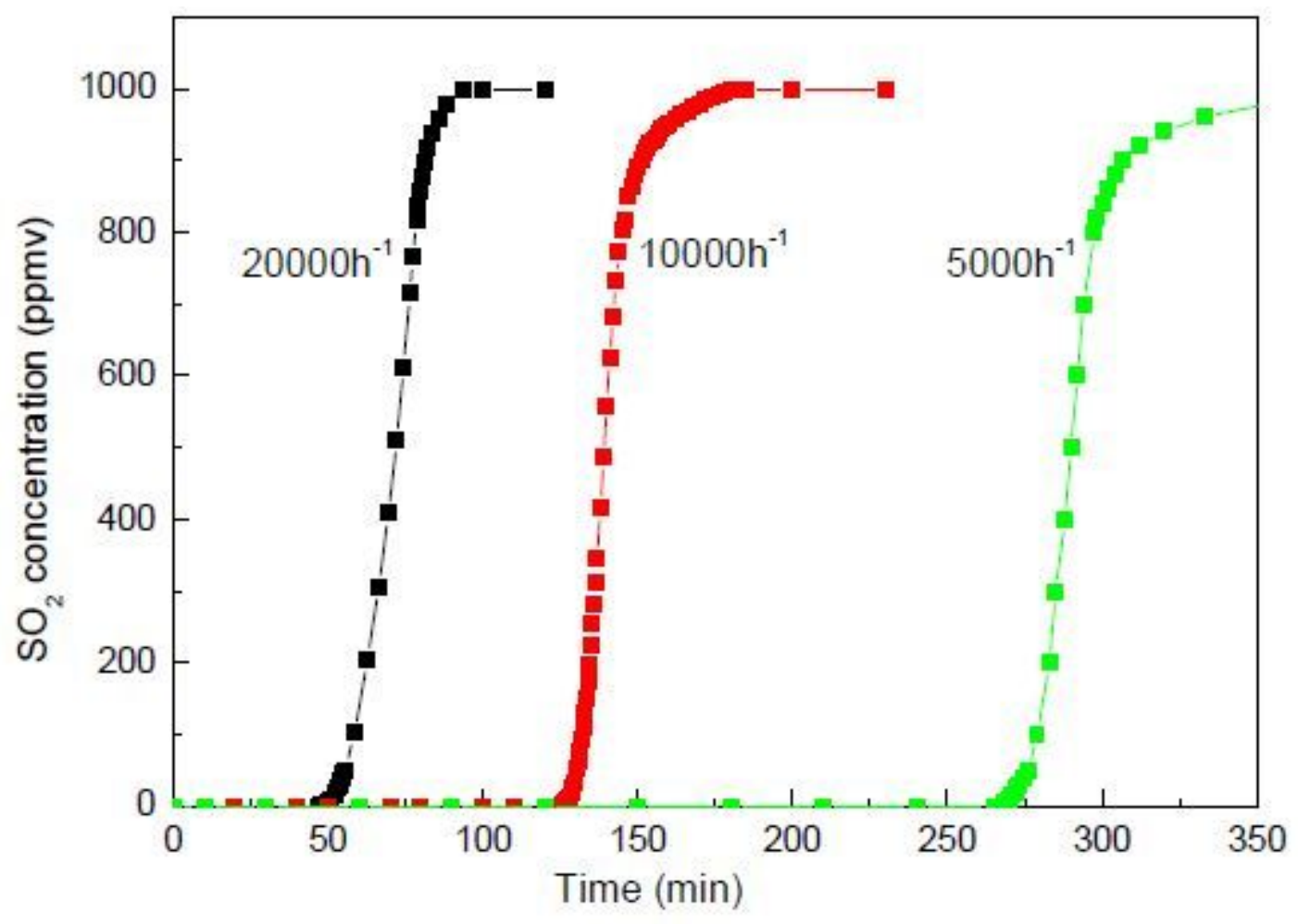

Figure 12 
Breakthrough curve of SO2 adsorption over CAC at various space velocity (SO2=1000 ppmv, $02=6 \mathrm{v} \%$, $\mathrm{T}=-20 \bigotimes$, flow rate $=1 \mathrm{~L} / \mathrm{min}$ )

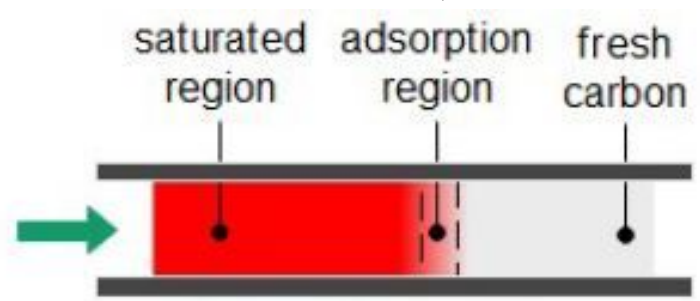

Adsorption Process

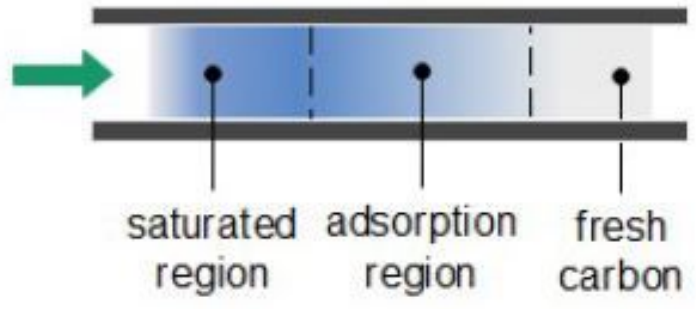

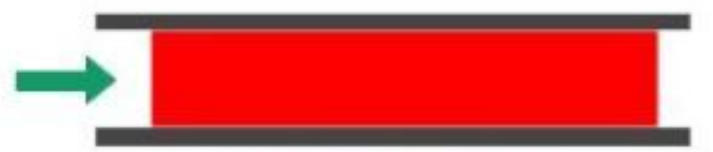

Saturated Status

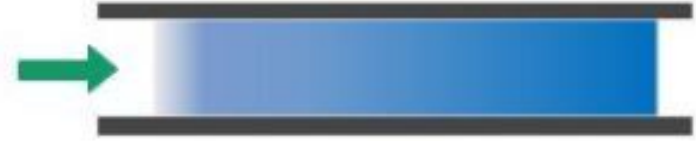

$\mathrm{SO}_{2}$

NOx

Figure 13

Adsorption process of SO2 and NO with presence of oxygen over activated carbon

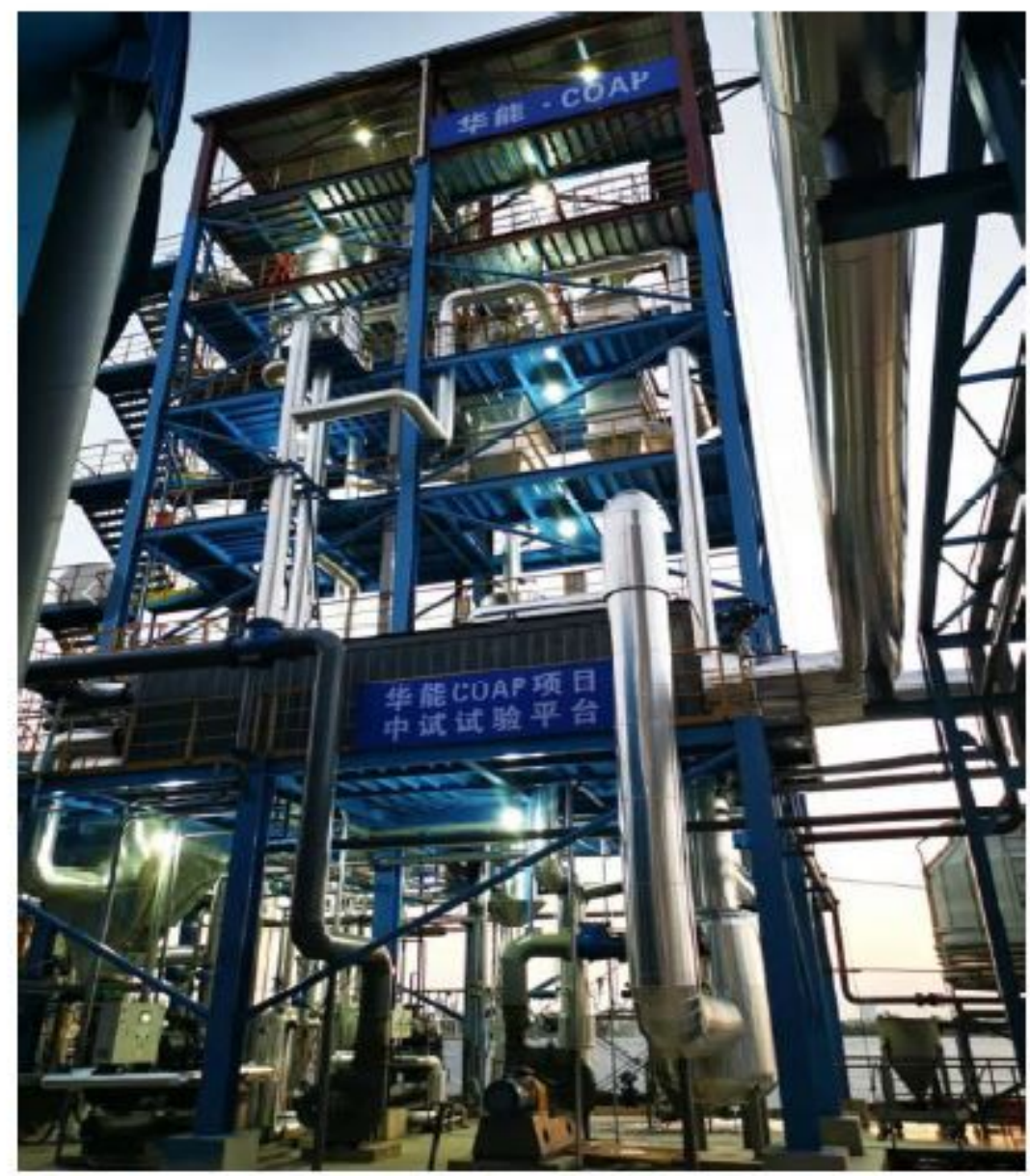

Figure 14 
A picture of pilot test platform of low-temperature adsorption desulfurization and denitrification

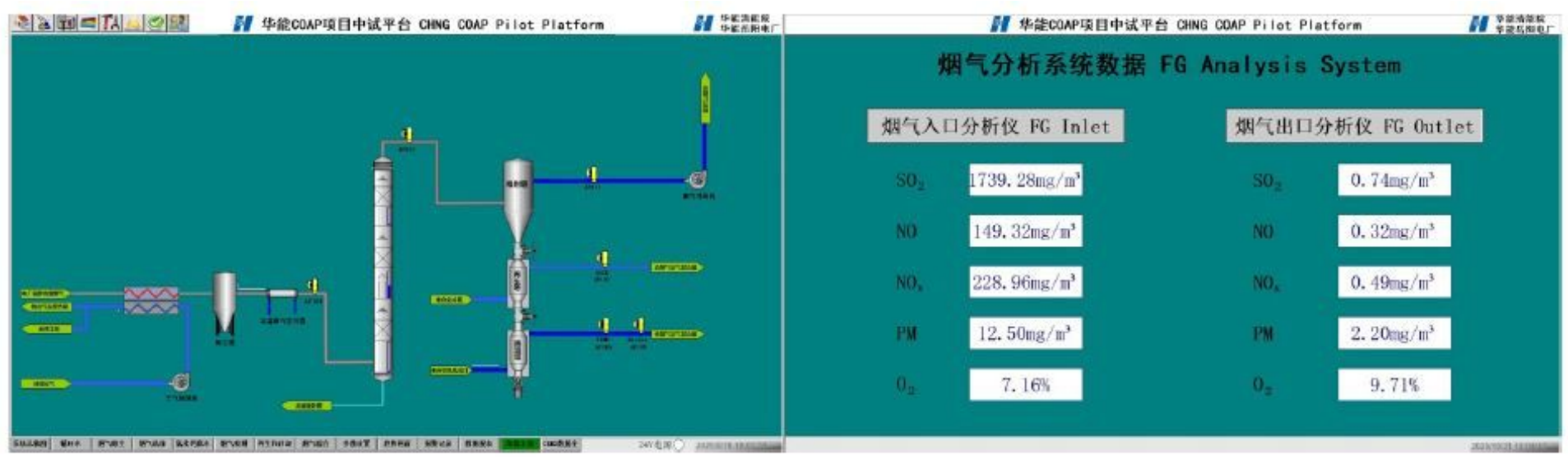

\section{Figure 15}

Process diagram and on-line flue gas monitoring and analysis system

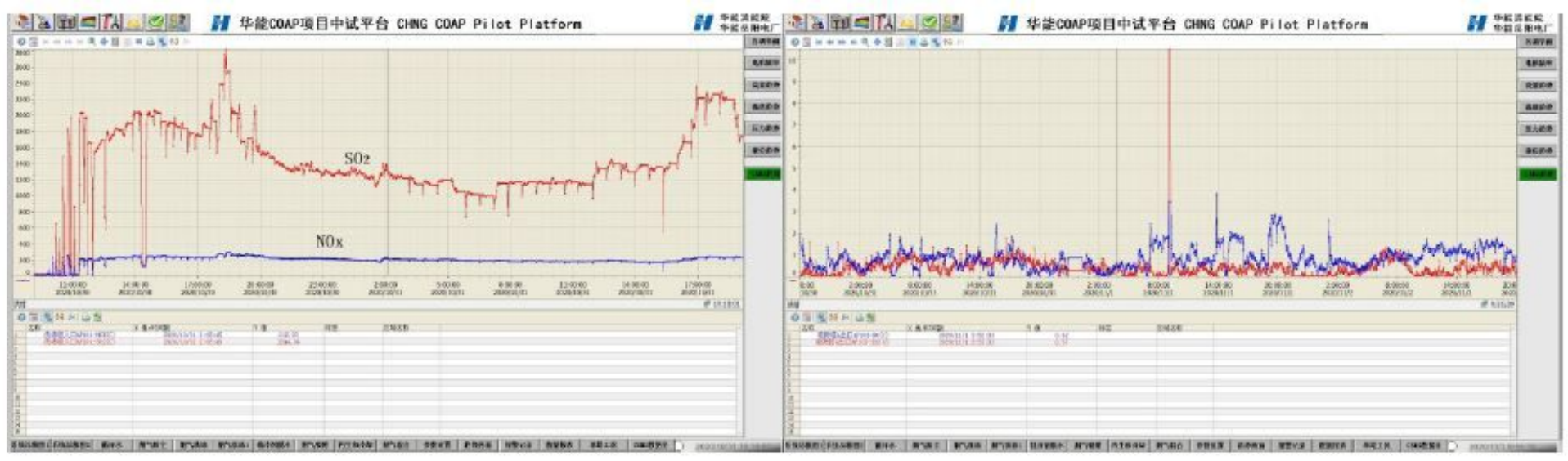

\section{Figure 16}

Inlet and outlet concentration of SO2 and NOx during $72 \mathrm{hrs}$ adsorption performance test 